Review

\title{
Food Safety through Natural Antimicrobials
}

\author{
Emiliano J. Quinto ${ }^{1, *}{ }^{\mathbb{D}}$, Irma Caro ${ }^{1}$, Luz H. Villalobos-Delgado ${ }^{2}$, Javier Mateo ${ }^{3}{ }^{\mathbb{D}}$, \\ Beatriz De-Mateo-Silleras ${ }^{1}$ and María P. Redondo-Del-Río ${ }^{1}$
}

1 Department of Nutrition and Food Science, Faculty of Medicine, University of Valladolid, 47005 Valladolid, Spain; irma.caro@uva.es (I.C.); bdemateo@yahoo.com (B.D.-M.-S.); pazr@ped.uva.es (M.P.R.-D.-R.)

2 Institute of Agroindustry, Technological University of the Mixteca, Huajuapan de León, Oaxaca 69000, Mexico; vidluz@mixteco.utm.mx

3 Department of Hygiene and Food Technology, Faculty of Veterinary Medicine, University of León, 24071 León, Spain; jmato@unileon.es

* Correspondence: equinto@ped.uva.es

Received: 24 September 2019; Accepted: 24 October 2019; Published: 31 October 2019

\begin{abstract}
Microbial pathogens are the cause of many foodborne diseases after the ingestion of contaminated food. Several preservation methods have been developed to assure microbial food safety, as well as nutritional values and sensory characteristics of food. However, the demand for natural antimicrobial agents is increasing due to consumers' concern on health issues. Moreover, the use of antibiotics is leading to multidrug resistant microorganisms reinforcing the focus of researchers and the food industry on natural antimicrobials. Natural antimicrobial compounds from plants, animals, bacteria, viruses, algae and mushrooms are covered. Finally, new perspectives from researchers in the field and the interest of the food industry in innovations are reviewed. These new approaches should be useful for controlling foodborne bacterial pathogens; furthermore, the shelf-life of food would be extended.
\end{abstract}

Keywords: natural antimicrobials; preservation; plants; spices; bacteria; viruses; algae; mushrooms; bacteriocins; bacteriophages

\section{Introduction}

Microbial pathogens are the cause of many foodborne diseases after the ingestion of contaminated food. Several preservation methods have been developed to assure microbial food safety, as well as nutritional values and sensory characteristics of food. Those methods sometimes have undesired effects on the nutritional and/or organoleptic aspects of food; synthetic preservatives are well known for causing health problems such as allergic reactions: nitrates, benzoates, sulfites, sorbates, formaldehyde, and phenolic antioxidants are good examples [1,2]. The use of natural antimicrobial food preservatives-biopreservation - could ensure the safety and quality of food being an alternative to other systems of preservation such as chemical or thermal ones. An excellent overview of natural antimicrobials applications can be seen in [1]. Biopreservation uses natural preservatives against a high number of pathogenic microorganisms related to food; those preservatives are obtained from animals, plants, bacteria, as well as mushrooms, algae, and viruses [2]. Figure 1 shows a general view of natural antimicrobials and their different roles in food safety. 


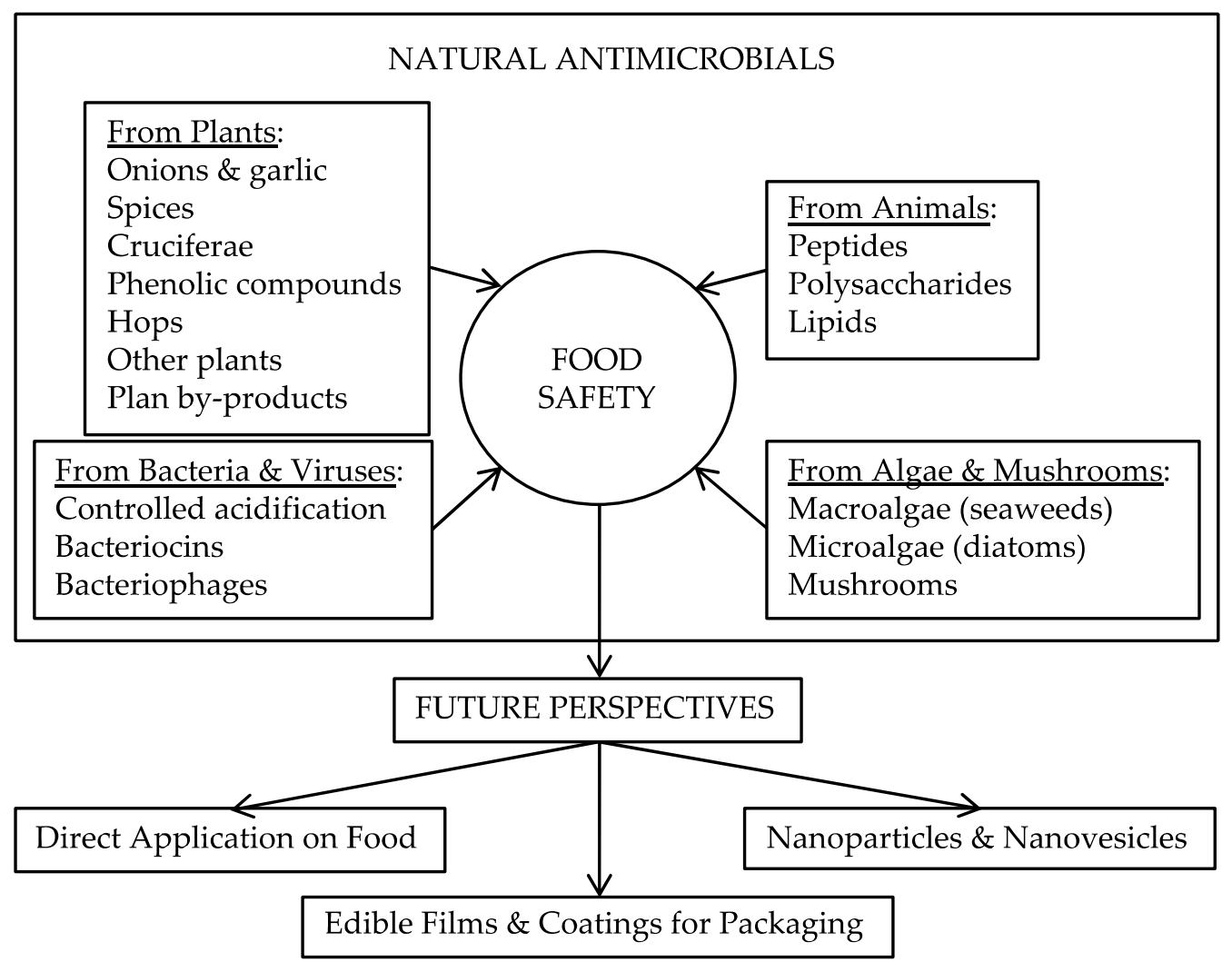

Figure 1. Overview of natural antimicrobials and their role in food safety.

The demand for natural antimicrobial agents is expected to increase steadily for replacing synthetic compounds [3]. A novel trend is arising from health-conscious consumers expecting that natural antimicrobials act only against foodborne pathogens leaving the consumers' microbiome out of their scope [1]. The negative effect of some synthetic preservatives on consumers' health is leading to more research to evaluate that natural antimicrobials fulfil food safety regulations [4]; the inadequate use of antibiotics leading to multidrug-resistant microorganisms also justify and reinforce the focus on natural antimicrobials [2]. Natural antimicrobials ensure food safety from a new perspective increasing its shelf-life; furthermore, their direct incorporation to different foods from different origins such as meat or vegetables as well as to their packaging give, as a result, the extension of their shelf-life $[1,5]$. They also constitute a viable alternative to microbial resistance caused by antibiotics.

Recent studies comparing natural derivatives from plants with synthetic antimicrobials have shown that natural substances could be safer $[3,6,7]$. The mechanisms of action of natural antimicrobials include the rupture of the cell membrane, affect the nucleic acids mechanisms, the decay of the proton motive force, and depletion of adenosine triphosphate (ATP). Antimicrobials from plants (polyphenols, essential oils), animals (lysozyme, lactoperoxidase, lactoferrin), metabolites from microorganisms, or extracts from algae use those mechanisms of action against foodborne bacteria $[1,8]$.

\section{Natural Antimicrobials from Plants}

Herbs and spices have most of the antimicrobials derived from plants [9-11]. These compounds have different structural configurations, having different antimicrobial actions against foodborne pathogens [12]. A fine review showing the different structural variations of plant-derived components and their effect on their antimicrobial capacities was published by Gyawali and Ibrahim [2]. The structural configuration of these compounds has big impact on their antimicrobial action, i.e. the hydroxyl $(-\mathrm{OH})$ groups are thought to be the cause; the reason behind that fact is the interaction of the 
hydroxyl groups with the bacterial cell membrane disrupting its structures and causing leakage of its components.

Growing interest in using antimicrobial plant-derived extracts is caused by the need to reduce the use of synthetic additives in food [13]. Antioxidant capacity usually joins the antimicrobial characteristics of these natural products; both properties together in one molecule makes the compound even more effective [1]. Plants and herbs (oregano, garlic, parsley, sage, coriander, rosemary, and lemongrass), spices (cinnamon, clove), oils (citral) or organic compounds (vanillin) have been used alone for their antimicrobial and antioxidant properties or in combination with other techniques for food preservation [14-16]. These authors also reported lower activity from products such as ginger, pepper, cumin, chilli, and curry. Gutierrez et al. [14] assessed combinations of essential oils from thyme, sage, rosemary, oregano, lemon, and basil against different microorganisms: Bacillus cereus, Escherichia coli, Listeria monocytogenes and Pseudomonas aeruginosa. Oregano showed efficacy against $B$. cereus; furthermore, the oregano combinations with basil or thyme were active against B. cereus, E. coli and P. aeruginosa. These authors also studied the effect of the $\mathrm{pH}$ and different ingredients from foods on the activity of thyme and oregano against L. monocytogenes; the kinetic parameters of the microorganism were more affected in foods with acidic $\mathrm{pH}$ and a high content in proteins. Proestos et al. [15] studied extracts from five plants-meadowsweet, hawthorn, polygonum, silverweed, and little robin-showing their antioxidant capacity, with total phenolic contents between 7.2-28.2 gallic acid equivalents/mg or $\mathrm{mL}$; their activity against the microorganisms showed that Gram-negative bacteria were less sensitive than Gram-positive. Numerous studies have been carried out using natural compounds extracted from plants against several microbial genera and/or species. Nanasombat and Lohasupthawee [17] studied the antimicrobial activity of extracts and essential oils from 14 spices tested against 20 serotypes of Salmonella and other members of the Enterobacteriaceae family, founding the following trend from greater to lesser degree of antimicrobial activity: Clove, cardamom, coriander, nutmeg, ginger, garlic, and basil among others. E. coli was the non-salmonellae strain more susceptible to most of the spice oils.

\subsection{Onions and Garlic}

The growth of many microorganisms is inhibited by onion and garlic. Several authors reported on the antimicrobial capacities of onions and garlic a long time ago [18-24]. Juices and vapours of these plants inhibit the growth of several microorganisms including bacteria (Bacillus cereus, Clostridium botulinum, Escherichia coli, Lactobacillus, Salmonella, Staphylococcus aureus, etc.) and fungi (Aspergillus spp., Candida, Saccharomyces, etc.) [23]. Conner et al. [18] reported that essential oils of onion (500 $\mu \mathrm{g} / \mathrm{mL})$ reduced the ethanol production by Sacchraromyces cerevisiae, suppressed the production of ethanol by Hansenula anomala, and delayed sporulation of Lodderomyces elongisporus. González-Fandos et al. [19] studied the inhibition of S. aureus growth and enterotoxin and thermonuclease production by garlic in brain heart infusion (BHI) broth. These authors found that S. aureus was inhibited at levels of $1.5 \%$ and over; enterotoxins $\mathrm{A}, \mathrm{B}$, and $\mathrm{C} 1$ were found with less than $1 \%$ of garlic, but at a $2 \%$ concentration the enterotoxin D was synthesized. Garlic inhibited thermonuclease production completely at levels greater or equal to $1.5 \%$. Barone et al. [22] reported fungicidal activity of garlic extracts $(68 \mu \mathrm{g} / \mathrm{mL})$ against 39 of 41 clinical strains of Candida albicans in standing culture; the extract was fungistatic (50-300 $\mu \mathrm{g} / \mathrm{mL}$ ) and fungicidal ( $>400 \mu \mathrm{g} / \mathrm{mL}$ ) in shake culture. A very interesting fact found by Barone et al. [22] was a loss of antimicrobial activity against $C$. albicans when the garlic extract was heat treated at $37^{\circ} \mathrm{C}$, having food safety implications in culinary processes; moreover, the activity against the microorganism was stable under acidic conditions, but unstable under base conditions. Kim et al. [24] studied the activity of garlic and onion essential oils and their sulfides against several bacteria and yeasts: S. aureus, E. coli, Enterobacter aerogenes, Leuconostoc mesenteroides, Pediococcus pentosaceus, Lactobacillus plantarum, Pichia membranefaciens, Saccharomyces cerevisiae, Candida utilis, Candida albicans, Zygosaccharomyces bisporus, and Zygosaccharomyces rouxii. The minimum inhibitory concentrations (MIC) of garlic and onion oils, diallyl-trisulfide and -tetrasulfide, and dimethyl-trisulfide were 2-45 ppm for the yeasts 
studied; however, these compounds had weak activity against most of the bacteria (MIC > 300 ppm). The activity against the tested yeasts was not influenced by the storage or the $\mathrm{pH}$.

\subsection{Spices}

As stated by Taylor and Davidson [23], spices are different parts (roots, seeds, leaves, fruits, etc.) of aromatic plants added as flavouring components to foods; among them, oregano, cinnamon, clove, and rosemary showed the greatest activity against microorganisms. Eugenol and cinnamic aldehyde are the major constituents of clove and cinnamon, respectively [23]. Cinnamon and cinnamic aldehyde have shown activity against bacteria (Aeromonas hydrophila, Bacillus spp., Campylobacter jejuni, verotoxin-producing E. coli, Lactobacillus, Listeria monocytogenes, Salmonella, Shigella, S. aureus, and Streptococcus) and fungi (Aspergillus, Candida, Penicillium, and Saccharomyces) [23,25-31]. Clove and eugenol are inhibitory to similar bacteria and fungi [28-39]. The antimicrobial effects of cinnamon alone or combined with potassium sorbate or sodium benzoate were tested against Escherichia coli O157:H7 at different temperatures in apple juice by Ceylan et al. [25]; the microorganism counts were reduced by approximately $2.0 \log$ colony forming units (CFU)/mL at 8 or $25^{\circ} \mathrm{C}$ by $0.3 \%$ cinnamon. Between cinnamon and the studied preservatives a synergistic activity was found: $0.3 \%$ of cinnamon combined with $0.1 \%$ of sodium benzoate or potassium sorbate killed $5 \log \mathrm{CFU} / \mathrm{mL}$ in 11 or $14 \mathrm{~d}$ at $8{ }^{\circ} \mathrm{C}$, respectively; the inhibitory effect was similar in $3 \mathrm{~d}$ by the same combinations at $25^{\circ} \mathrm{C}$. Thyme, oregano, dictamus, marjoram, lavender, rosemary, and sage were tested against Penicillium digitatum by Daferera et al. [26]; the growth and germination were inhibited by the essential oils of dictamus, marjoram, oregano, and thyme at $250-400 \mu \mathrm{g} / \mathrm{mL}$, while lavender, rosemary, and sage were less effective. Friedman et al. [28] studied the activity of 119 essential oils against bacteria isolated from foods and clinical sources (Campylobacter jejuni, E. coli O157:H7, L. monocytogenes, and Salmonella enterica) founding that 39 oils were active against all four species of bacteria. Nielsen et al. [30] investigated the effect of spices and herbs oils and oleoresins against bread spoilage fungi (Penicillium commune, P. roqueforti, Aspergillus flavus, and Endomyces fibuliger) as an alternative to modified atmosphere packaging. Cinnamon, clove, garlic, and mustard had high activity, while oregano had weak activity against the growth of fungi; the more resistant microorganisms was A. flavus, and P. roqueforti the most sensitive.

The activities against the microorganisms of oregano and thyme have been assigned to carvacrol and thymol, respectively [23], showing activity against the bacteria Aeromonas spp., B. cereus, Brochothrix thermosphacta, Campylobacter jejuni, Escherichia coli, Enterobacter faecalis, Lactobacillus plantarum, Listeria monocytogenes, Pediococcus cerevisiae, Pseudomonas, Proteus, Salmonella, Shigella, Staphylococcus aureus, Vibrio parahaemolyticus, and Yersinia enterocolitica [7,34,40-51], and the moulds and yeasts Aspergillus, Candida, Geotrichum, Penicillium, Pichia, Rhodotorula, Saccharomyces cerevisiae, and Schizosaccharomyces pombe [52-59]. Burt and Reinders [7] quantified the antibacterial effect against E. coli O157:H7 of several essential oils with or without a stabilizer (such as agar) and an emulsifier (lecithin) at different temperatures. Oregano and thyme essential oils had the strongest properties; $0.05 \%$ of agar reinforced the activity of the essential oils at $10{ }^{\circ} \mathrm{C}$, whereas the addition of $0.25 \%$ of lecithin reduced their activity. These authors reported that the combination of oregano or thyme with agar reduces the number of E. coli O157:H7 preventing its growth. Of 17 spices and herbs tested at $0.5-1 \%$, only clove, basil, marjoram, oregano, rosemary, and thyme showed activity against Shigella spp. [34]. These authors combined temperature $\left(12,22\right.$, and $\left.37^{\circ} \mathrm{C}\right), \mathrm{pH}(5.0,5.5$, and 6.0$), \mathrm{NaCl}(1-4 \%)$, and thyme or basil ( 0 or $1 \%$ ), establishing that both can contribute as an inhibitory factor: S. flexneri did not grow for $7 \mathrm{~d}$ with basil and/or thyme, while growth was noted without them. The practical side of the study was the use of these spices in spaghetti sauce founding that, at $12{ }^{\circ} \mathrm{C}$, the population of $S$. sonnei decreased after $16 \mathrm{~d}$; the population did not reduce its counts at $4{ }^{\circ} \mathrm{C}$. Seaberg et al. [41] addressed the fact that different batches of the same plant species have a genetic heterogeneity that represents a problem for their use against microbial growth and for achieving the "clean label" for the food industry. To overcome the situation, a clonal line of oregano was isolated, and its ethanol extracts together with 
its main constituents - thymol and carvacrol-were used in both broth and meat systems to study its activity against Listeria monocytogenes; all thymol and carvacrol (150-200 ppm) and the clonal line (1200 ppm) inhibited the L. monocytogenes growth in both systems. Singh et al. [42] also evaluated the activity of essential oils from different plants against Listeria monocytogenes in peptone water and hotdogs, finding that thyme and clove $(1 \mathrm{~mL} / \mathrm{L})$ were highly effective inhibiting the population of L. monocytogenes below detection limits. Carvacrol was also investigated by Ultee et al. [43] for its effect on Bacillus cereus and the production of diarrheal toxin; its counts were reduced with concentrations of about $0-0.06 \mathrm{mg} / \mathrm{mL}$ in BHI broth-an $80 \%$ decline in toxin production was detected with $0.06 \mathrm{mg} / \mathrm{mL}$. Carvacrol, thymol, cymene, and terpinene were studied against E. coli O157:H7 by Burt et al. [45] and Kiskó and Roller [47]; carvacrol and thymol were additive in combination showing bacteriostatic and bactericidal activities $(1.2 \mathrm{mmol} / \mathrm{L})$, and cymene and terpinene did not show antibacterial activity up to $50 \mathrm{mmol} / \mathrm{L}$. The inhibitory activity of several natural compounds (thymol, carvacrol, eugenol, cinnamic acid, and diacetyl) alone or in combination with nisin against E. coli and Salmonella enterica serovar Typhimurium [48], or Bacillus subtilis and Listeria innocua [49] was studied. Nisin alone showed no antibacterial activity. Thymol was the most effective with concentrations of 1.0-1.2 mmol against S. enterica and E. coli; the combination of nisin showed no improvement of the antimicrobial activity. All the organic compounds exhibited activity against the Gram-positive microorganisms with concentrations between 0.8 and $15.0 \mathrm{mM}$; the interaction between the organic compounds and nisin showed different patterns, varying from synergistic (carvacrol, eugenol, or thymol; nisin plus cinnamic acid only against L. innocua) to antagonistic (nisin plus diacetyl). The anticandidal activity of the major phenolic compounds of oregano (carvacrol at $0.1 \%$ ) and clove (eugenol at $0.2 \%$ ) essential oils was studied by Chami et al. [53]. Both compounds were fungicidal in exponentially growing Candida albicans. Also using Candida albicans, the activity of origanum, carvacrol, nystatin, and amphotericin B were tested by Manohar et al. [57]. C. albicans growth was completely inhibited by origanum oil at $0.25 \mathrm{mg} / \mathrm{mL}$; origanum oil and carvacrol inhibited both germination and mycelial growth in a dose-dependent manner.

Sage (containing thujone) and rosemary (with borneol, pinene, camphene, and camphor) also have antimicrobial activity [23,44]. Oregano, thyme and savoury [7], and sage and rosemary [60,61] essential oils showed pronounced bactericidal properties against E. coli O157:H7 and other foodborne pathogens. Pirbalouti et al. [62] reported antibacterial activity against L. monocytogenes by several plant extracts including essential oils from Thymus spp. In contrast, other authors $[42,54,59,63]$ have found that essential oil of spices had little antimicrobial activity against bacteria and yeasts may be due to the assays utilized [23].

Several other spice essential oils have shown potential for antibacterial and antifungal activity. Sweet basil demonstrated activity against fungi such as Mucor and Penicillium although little activity against bacteria [23,64]; the main agents are linalool and methyl chavicol [23]. Essential oils from different varieties of sweet basil were tested for their activity against Gram-positive and Gram-negative foodborne bacteria, yeasts, and moulds by Lachowicz et al. [64]; all basil's essential oils showed activity against the microorganisms tested with the exception of Flavimonas oryzihabitans and Pseudomonas spp. Vanilla beans have vanillin as their major constituent, being most active against moulds and Gram-positive bacteria $[23,65]$. Delaquis et al. [65] studied the activity of vanillin and vanillic acid against Listeria monocytogenes, L. innocua, L. grayi, and L. seeligeri. All strains were inhibited by concentrations of about 23-33 mM; concentrations of about $100 \mathrm{mM}$ vanillic acid at $\mathrm{pH}>6.0$ was not effective against the microorganisms, but with $10 \mathrm{mM}$ at $\mathrm{pH} 5.0$ the inhibition was complete. A declining $\mathrm{pH}$ increased the lethal activity of vanillic acid, and vanillin plus vanillic acid gave additive inhibitory effects.

Other essential oils from spices have potential antimicrobial activity as well as antifungal, such as cilantro-also known as coriander, fingerroot, lemongrass, savory, and tea tree oil $[23,28,44,58,61,66-70]$. 


\subsection{Cruciferae}

Cabbage, cauliflower, broccoli, Brussels sprouts, horseradish, kale, kohlrabi, mustard, turnips, and rutabaga are members of this family. Isothiocyanates are reported as antimicrobial agents [23] against bacteria (E. coli O157:H7, L. monocytogenes, Salmonella, S. aureus, Serratia, Lactobacillus sake, Pseudomonas, and Enterobacteriaceae) [71-73] and fungi and yeast (Penicillium expansum, Aspergillus flavus, and Botrytis cinereal) [74].

Delaquis et al. [71] and Ward et al. [72] tested the behaviour of bacteria in pre-cooked roast beef with vaporized horseradish essential oil at $4{ }^{\circ} \mathrm{C}$ for $28 \mathrm{~d}$. Pseudomonas spp. and some members of the family Enterobacteriaceae were inhibited; lactic acid bacteria were more resistant. Interestingly, the colour of the cooked meat was preserved in samples stored with horseradish essential oil. The growth of S. aureus, E. coli O157:H7, S. typhimurium, L. monocytogenes, and Serratia grimesii was inhibited at $12{ }^{\circ} \mathrm{C}$ for $7 \mathrm{~d}$ of storage under aerobic conditions.

\subsection{Phenolic Compounds}

Monophenols, diphenols, and triphenols are simple phenolic compounds. The use of wood smoke for food preservation implies the use of simple phenols (cresol, hydroquinone, gallic acid); additionally, their use gives a desirable flavour [23]. Liquid smoke is a method widely used in cheese surface inhibiting the growth of fungi such as Aspergillus oryzae, Penicillium camemberti, and Penicillium roqueforti [75]; these authors found that only isoeugenol inhibited all these molds. Cresol (forms $\mathrm{m}$ and $\mathrm{p}$-) slightly inhibited the growth of P. camemberti, and guaiacol, 4-methylguaiacol, and $\mathrm{m}$ - and p-cresol inhibited the growth of $A$. oryzae.

The phenolic acids are present in plants and can inhibit bacteria such as Aeromonas hydrophila, E. coli, E. faecalis, Salmonella serovar Enteritidis, L. monocytogenes, and S. aureus, [23,76]. The most effective compound was the phenolic antioxidant tertiary butylhydroquinone with MIC of $64 \mu \mathrm{g} / \mathrm{mL}$ [76].

Hydroxycinnamic acids (such as caffeic, coumaric, ferulic, and sinapic acids) have different inhibition effects against B. cereus and S. aureus; P. fluorescens and E. coli are more resistant to them $[23,77]$. It has been reported the antifungal properties of hydroxycinnamic acids, i.e., inhibiting the production of aflatoxins from A. flavus and A. parasiticus [23,78]. Herald and Davidson [77] reported the antibacterial activity of caffeic, ferulic, and p-coumaric acids against Escherichia coli, Staphylococcus aureus, and Bacillus cereus; p-coumaric acid was the most effective against $E$. coli with concentrations of about $1000 \mu \mathrm{g} / \mathrm{mL}$ at $\mathrm{pH} 5.0$ for $48 \mathrm{~h}$, and S. aureus and B. cereus with concentrations of about $500 \mu \mathrm{g} / \mathrm{mL}$ at $\mathrm{pH} 5.0$ for $48 \mathrm{~h}$ or at $\mathrm{pH} 7.0$ for $9 \mathrm{~h}$, respectively. Inhibition increased as $\mathrm{pH}$ decreased with $E$. coli and S. aureus but not B. cereus. Chipley and Uraih [78] studied the antimicrobial activity of o-nitrobenzoate, p-aminobenzoate, ethyl aminobenzoate, ethyl- and methyl-benzoate, salicylic acid, trans-cinnamic acid, trans-cinnamaldehyde, ferulic acid, o-acetoxy benzoic acid, and anthranilic acid on Aspergillus flavus and A. parasiticus growth and aflatoxin production at $27^{\circ} \mathrm{C}$. Both methyl- and ethyl-benzoate were the most effective at concentrations of about $2.5-5.0 \mathrm{mg} / 25 \mathrm{~mL}$ of medium reducing the mycelial growth and the aflatoxin production.

Furocoumarins are present in carrots, celery, citrus fruits, parsley, and parsnips. Several authors reported their antimicrobial activity against E. coli O157:H7, Erwinia carotovora, L. monocytogenes, and Micrococcus luteus $[23,79]$. The antimicrobial activity of furanocoumarins against $L$. monocytogenes, E. coli O157:H7, and Micrococcus luteus was investigated in a model food system (25\% commercial vegetable baby food in peptone water) by Ulate-Rodríguez et al. [79]. The growth of L. monocytogenes was inhibited with lime peel extract and cold-pressed lime oil, but not the growth of E. coli O157:H7; $M$. luteus counts were inhibited only by the cold-pressed lime oil. The minimum inhibitory and the minimum bactericidal concentrations of L. monocytogenes were 32 or $43 \mu \mathrm{g} / \mathrm{g}$, respectively.

Flavonoids, such as catechins, flavons, flavonols, and their glycosides, are present in apples, barley, grapes, plums, sorghum, and strawberries [23,80]. Cushnie and Lamb [80] reported antifungal, antiviral, and antibacterial activity. Quercetin activity was attributed to the inhibition of the enzyme DNA gyrase; the inhibition of the cell membrane functions by the activity of sophoraflavone $G$ and 
(-)-epigallocatechin gallate was reported and, moreover, the inhibition of the energy metabolism by the licochalcones A and C [80]. Other studied flavonoids are 2,4,2'-trihydroxy-5'-methyl chalcone, apigenin, galangin, lonchocarpol $\mathrm{A}$, myricetin, robinetin, and rutin.

\subsection{Hops}

The hop (Humulus lupulus L.) flower's resin is used in the brewing industry for the bitter flavour it gives to beer [23]. Hop contains compounds (prenylated acylphloroglucinols and xanthohumol) that have inhibited bacteria growth, mostly Gram-positive [81-87]. The use of bitter acids as antimicrobials was approved by the Food Safety and Inspection Service (FSIS), USA [88]. Kramer et al. [81] studied the effect of hop extracts against some pathogens related with food using in vitro and meat model applications at 2 and $8{ }^{\circ} \mathrm{C}$. The MIC of hop extracts with bitter acids ( $\alpha$-and $\beta$-acids) or xanthohumol were tested against E. coli, S. aureus, S. enterica, and L. monocytogenes. The xanthohumol and the $\beta$-acid inhibited the growth of the Gram-positive bacteria (MICs of 12.5 and $6.3 \mathrm{ppm}$, respectively), and the $\alpha$-acid was less active (MIC of $200 \mathrm{ppm}$ ); in contrast, the Gram-negative bacteria were highly resistant. These authors concluded that "hop extracts could be used as natural preservatives in food applications to extend the shelf life and to increase the safety of fresh products." Bogdanova et al. [82] investigated the antibiofilm properties of hop compounds (humulone, lupulone, and xanthohumol) against Staphylococcus spp., including strains that were methicillin-susceptible and resistant. All compounds showed antimicrobial activity against all strains; lupulone, followed by xanthohumol had the strongest effect. Lupulone and xanthohumol penetrated the biofilm reducing the number of cells or reducing completely their number at the higher concentrations (lupulone: $125 \mu \mathrm{g} / \mathrm{mL}$; xanthohumol: $60 \mu \mathrm{g} / \mathrm{mL}$ ). Hop extracts showed different grades of inhibition against L. monocytogenes in food [86]: In coleslaw, $1 \mathrm{mg} / \mathrm{g}$ of hop extract increased the inactivation; in milk, $0.1-1 \mathrm{mg} / \mathrm{mL}$ was inhibitory; and in cottage cheese, hop extract was bactericidal at $0.1-3 \mathrm{~g} / \mathrm{kg}$. These authors concluded that, overall, the activity against $L$. monocytogenes in food was enhanced with acidity and lower fat content.

Some fungi are inhibited by hop acids [89,90] as well as protozoa [91]. Mizobuchi et al. [89] isolated a new flavonone (6-isopentenylnaringenin) from hard resins of hops; it was tested together with xanthohumol and isoxanthohumol showing antifungal activities against Candida albicans, Fusarium oxysporum, Trichophyton mentagrophytes and T. rubrum, and Mucor rouxianus. Srinivasan et al. [91] studied the antimicrobial spectrum of hop acid components for antiprotozoal activity, founding that ciliated protozoa were more sensitive than amoebae; plasmodia were sensitive but at a lower level than to the anti-malarial drugs. Xanthohumol was particularly potent, and the effect was enhanced by carbon dioxide.

\subsection{Other Plants}

Ahn et al. [92] focused their studies on the extracts from grape seed and pine bark; these authors found that their extracts can be used against E. coli O157:H7, S. enterica serovar Typhimurium, and L. monocytogenes in vitro and ground beef. The populations of E. coli O157:H7, S. enterica serovar Typhimurium, and L. monocytogenes decreased below $10 \mathrm{CFU} / \mathrm{mL}$ after $16 \mathrm{~h}$. Markin et al. [93] studied olive leaves extracts founding deadly effects on bacteria, dermatophytes, and yeast. Olive leaf $0.6 \%$ extract killed within $3 \mathrm{~h}$ almost all cells from cultures of E. coli, B. subtilis, Klebsiella pneumoniae, Pseudomonas aeruginosa, and S. aureus; $1.25 \%$ after $3 \mathrm{~d}$ inhibited the growth of dermatophytes such as Microsporum canis, Trichophyton mentagrophytes and T. rubrum, whereas $15 \%$ of plant extract killed after $24 \mathrm{~h}$ of incubation all the cells from the yeast Candida albicans. Dogasaki et al. [94] and Ibrahim et al. [95] mentioned the antibacterial properties of coffee and its compounds such as caffeic acid, chlorogenic acid, and protocatechuic acid; these compounds inhibited the growth of Legionella pneumophila and E. coli O157:H7, respectively. Furthermore, tea (Camellia sinensis) was also demonstrated to feature antimicrobial properties [96-98] through its predominant catechin, epigallocatechin gallate, against methicillin-resistant $S$. aureus. Shan et al. [99] reported the activity of cinnamon stick extracts (Cinnamomum burmanii Blume) against B. cereus, E. coli, L. monocytogenes, S. aureus, and Salmonella 
anatum. Major compounds in the cinnamon stick were identified: E-cinnamaldehyde and polyphenols; both components significantly contributed to the antimicrobial properties.

\subsection{Plant By-Products}

Large amounts of by-products are generated during the food processing of plants, such as fruit pomace, husks, kernels, peels, pulps, seeds, and unused flesh [2]. Usually considered as a waste, these by-products possess bioactive compounds with antimicrobial activity being promising sources for their commercial exploitation; Gyawali and Ibrahim [2] list some plant by-products as antimicrobials.

Extracts of grape pomane [100] and olive pomace [101,102] have shown to be able to inhibit the growth of E. coli, Enterobacter spp., S. aureus, Salmonella spp., and L. monocytogenes, and other spoilage and pathogenic bacteria. Sagdic et al. [100] incorporated grape pomace extracts into beef patties at different concentrations: $1-10 \%$ for 12,24 and $48 \mathrm{~h}$. All the microorganisms tested (Enterobacteriaceae and spoilage microorganisms) were inhibited at a concentration of $10 \%$ in all the storage periods. Friedman et al. [101] evaluated the bactericidal activity of 10 food-based powders against E. coli O157:H7, S. enterica, S. aureus, and L. monocytogenes. Olive pomace, juice powder, and leaves were active against all bacteria. All powders had strong activity against $S$. aureus.

Fruit peels are also important. Pomegranate fruit peels extracts showed their antimicrobial activity enhancing the shelf-life of chicken products [103], and their ability to inhibit the growth of E. coli, B. cereus, L. monocytogenes, S. aureus, and Y. enterocolitica [104-106]. Pomegranate peel showed good activity against $S$. aureus and B. cereus (MIC of 0.01\%); concentrations of $0.1 \%$ inhibited Pseudomonas but E. coli and S. typhimurium. The shelf life of chicken products was enhanced by $2-3$ weeks with the addition of pomegranate peel during chilled storage [103]. Li et al. [105] investigated the activity of the tannin-rich fraction from pomegranate rind against L. monocytogenes; punicalagin and ellagic acid were detected, and the MICs against L. monocytogenes strains were $1.25-5.0 \mathrm{mg} / \mathrm{mL}$. The same research group [106] evaluated the effects of the same fraction on both the virulence gene expression and the $L$. monocytogenes interaction with the epithelial cells. The adhesion to and the invasion of Caco- 2 cells were reduced at $2.5 \mathrm{mg} / \mathrm{mL}$. Guava, jackfruit, mango, papaya, plum, tamarind, and their seeds were effective against B. subtilis, E. coli, S. aureus, and P. aeruginosa [107]. A major fruit by-product is tomato seeds from the tomato processing industry; tomato seeds extracts have shown inhibition of Gram-positive bacteria and fungi [108]. These authors studied the antimicrobial potential of tomato seed extracts against Gram-positive (Bacillus cereus, Enterococcus faecalis, Micrococcus luteus, Staphylococcus aureus and S. epidermidis) and Gram-negative (E. coli, Proteus mirabilis, Pseudomonas aeruginosa, and S. typhimurium) bacteria and fungi (Aspergillus fumigatus, Candida albicans, and Trichophyton rubrum). E. faecalis was the most susceptible Gram-positive bacteria (MIC of 2.5-10 mg/mL). C. albicans was the most susceptible fungal species (MIC of 5-10 mg/mL).

Coffee husks, peel, and pulp are some of the main by-products obtained from coffee processing industry $[2,109,110]$; extracts from these by-products contain large amounts of phenolic compounds (tannins, flavonols, flavandiols, flavonoids, and phenol acids) and are potential natural preservatives for food [2]. Quoting Taveira et al. [108] and Gyawali and Ibrahim [2], "the waste produced by the food-processing industry could be incorporated into antimicrobial packaging or utilized as edible antimicrobial films".

\section{Natural Antimicrobials from Animals}

Some of the animal defence mechanisms have antimicrobial properties [1,23] destroying the cell membranes [1,60] and killing both Gram-negative and -positive bacteria [1].

\subsection{Peptides}

Antimicrobial peptides from animal origin have a broad range of antibacterial activities as well as antiviral [111]. 
Pleurocidin is a peptide with antimicrobial activity found in the skin secretions of the winter flounder (Pleuronectes americanus) [112], and it is active against Gram-positive and -negative bacteria such as E. coli O157:H7, L. monocytogenes, Saccharomyces cerevisiae, Penicillium expansum, and Vibrio parahemolyticus [113,114]. Burrowes et al. [113] evaluated pleurocidin in food applications using 18 microbial species. Pleurocidin was effective against E. coli O157:H7, L. monocytogenes, P. expansum, S. cerevisiae, and V. parahemolyticus with MIC of 5.3, 23.0, 20.6, 5.5, and $69 \mu \mathrm{M}$, respectively; no haemolytic or cytotoxic effect on intestinal cells were found. Patrzykat et al. [114] identified peptide effects studying a flounder pleurocidin and frog dermaseptin hybrid. At $2 \mu \mathrm{g} / \mathrm{mL}$, dermaseptin inhibited the growth of E. coli but did not kill the cells within $30 \mathrm{~min}$; concentrations equal to or higher than $20 \mu \mathrm{g} / \mathrm{mL}$ reduced the viable counts by $2 \log$ within $5 \mathrm{~min}$. Pleurocidin showed variations of this antimicrobial pattern.

Other antimicrobial peptides are defensins, protamine, magainin, and casocidin [1]. Defensins are produced by vertebrates-phagocytes of mammals and epithelial cells, with antimicrobial properties against bacteria and fungi, as well as viruses [60]. Protamine and magainin are active against bacteria and fungi $[60,115]$ : protamine is a protein obtained from sperm cells of vertebrates [116], and magainin from the skin of the frog Xenopus laevis $[117,118]$. Protamine is a cationic peptide; its activity against microorganisms is probably due to its electrostatic affinity to negatively charged bacteria. Potter et al. [115] tested this hypothesis in model broth (tryptic soy broth) and food systems (milk and ground beef). The analysis of 21 bacteria revealed that the most negatively charged were also the most susceptible. Kim et al. [116] investigated the suppressive effects of protamine on the growth of oral pathogens; 12 strains of streptococci, Actinomyces naeslundii and A. odontolyticus, Aggregatibacter actinomycetemcomitans, Candida albicans, Enterococcus faecalis, Fusobacterium nucleatum, Lactobacillus acidophilus, and Porphyromonas gingivalis were inhibited (MIC of 0.009-20 mg/mL). Zasloff [117] tested magainin for its antibacterial activity founding that, at low concentrations, inhibited the growth of numerous species of bacteria (E. coli, Enterobacter cloacae, Klebsiella pneumoniae, Staphylococcus epidermidis, Staphylococcus aureus, Citrobacter freundii, Pseudomonas aeruginosa, Pseudomonas putida, Serratia marcescens, Proteus mirabilis, and Streptococcus fecalis) and fungi (Saccharomyces cerevisiae, Cryptococcus neoformans, and Candida albicans) and induce osmotic lysis of protozoa (Amoeba proteus, Euglena gracilis, and Paramecium caudatum). Casocidin is another peptide obtained from bovine milk with antibacterial activity against E. coli and Staphylococcus carnosus [119]. The primary structure of casocidin is a fragment of 39 amino acids of bovine $\alpha$ s2-casein. The casein- $\alpha \mathrm{s} 2$ is not present in human milk, so Zucht et al. [119] hypothesized that "these findings could explain the different influence of human and bovine milk on the gastrointestinal flora of the suckling."

Lactoferrin is a peptide with capacity against Gram-positive and -negative bacteria, fungi, and parasites [2,120,121]. Murdock et al. [120] determined whether nisin and lactoferrin would act synergistically against L. monocytogenes and E. coli O157:H7. L. monocytogenes was inhibited with $1000 \mu \mathrm{g} / \mathrm{mL}$ of lactoferrin, although E. coli O157:H7 counts initially decreased and then recovered to cell counts similar to the control. Lactoferrin $(500 \mu \mathrm{g} / \mathrm{mL})$ plus nisin $(250 \mathrm{IU} / \mathrm{mL})$ effectively inhibited the E. coli O157:H7 growth, whereas $250 \mu \mathrm{g} / \mathrm{mL}$ plus $10 \mathrm{IU} / \mathrm{mL}$, respectively, had an inhibitory effect suggesting that lactoferrin and nisin act synergistically to inhibit both microorganisms. López-Expósito et al. [121] studied whether the antimicrobial activity of nisin could be enhanced by lactoferrin $\mathrm{f}$ and $\alpha \mathrm{s} 2$-casein $\mathrm{f}$ against Escherichia coli, Listeria monocytogenes, Salmonella choleraesuis, and Staphylococcus epidermidis. Results showed a synergistic effect against E. coli and S. epidermidis; moreover, another synergistic effect was found between $\alpha$ s2-casein $\mathrm{f}$ and nisin against L. monocytogenes because of its capacity to develop resistance to nisin. Lactoferrin binds iron [1,2] and is used as antimicrobial in meat products [122]. Murdock et al. [120] and Al-Nabulsi and Holley [123] reported the antimicrobial activity of lactoferrin against foodborne bacteria such as E. coli, Carnobacterium spp., Klebsiella, and L. monocytogenes. Lactoferrin in a concentration of about $8 \mathrm{mg} / \mathrm{mL}$ killed $4 \log$ CFU/mL of Carnobacterium viridans at 4,10 and $30{ }^{\circ} \mathrm{C}$ and neutral $\mathrm{pH}$ in a broth system [123].

Lactoperoxidase is a protein (glycoprotein enzyme) present in raw milk, colostrum, saliva, and other secretions $[23,124]$. Lactoperoxidase reacts with thiocyanate and hydrogen peroxide forming 
the termed lactoperoxidase system (LPS) with antimicrobial capacities. Thiocyanate is found in milk and other animal secretions by the metabolism of amino acids and glucosides from the diet or by detoxification of thiosulfates. Hydrogen peroxide is not present in milk, so it needs to be added, or obtained from lactic acid bacteria activity or enzymatic action [23,124,125]. Potential mechanisms used by the LPS were reviewed by Bafort et al. [125]. The LPS inhibits both Gram-positive and -negative pathogens including E. coli O157:H7, Y. enterocolitica, Salmonella, S. aureus, L. monocytogenes, C. jejuni and $P$. aeruginosa in different foods [23,124,126-130]. Elliot et al. [127] assessed the growth of E. coli O157:H7, L. monocytogenes, S. aureus, S. enterica subsp. enterica serovar Typhimurium, Pseudomonas aeruginosa, Yersinia enterocolitica, and beef microbiota on meat surfaces treated with the LPS at $37^{\circ} \mathrm{C}$ for $24 \mathrm{~h}, 12{ }^{\circ} \mathrm{C}$ for $7 \mathrm{~d}, 12$ to $-1{ }^{\circ} \mathrm{C}$ for 1 week, and $-1{ }^{\circ} \mathrm{C}$ for 4 weeks. LPS was more effective at refrigeration temperatures, inhibiting the growth of Pseudomonas from beef microbiota but of lactic acid bacteria. McLay et al. [128] evaluated an LPS-monolaurin system (5-200 mg/kg of lactoperoxidase and 50-1000 ppm of monolaurin) for the inhibition of E. coli O157:H7 and Staphylococcus aureus in growth, milk and ground beef. In broth, the growth of both microorganisms was inhibited more strongly than in milk, and in milk more than in ground beef. The potential use of the LPS in broth at $37^{\circ} \mathrm{C}$ and ground meat preparations at 0,6 , and $12{ }^{\circ} \mathrm{C}$ was examined by Kennedy et al. [129]. L. monocytogenes was the most sensitive, followed by Staphylococcus aureus and E. coli O157:H7. The inhibition was highly dependent of the temperature: it was maximal at a temperature adequate but not optimal for the bacterial growth. The LPS was tested against Salmonella enteritidis in tomato and carrot juices, milk, liquid whole egg, and chicken skin extract under different conditions [130]; at low $\mathrm{pH}$ and $30{ }^{\circ} \mathrm{C}, \mathrm{LPS}$ was more effective in vegetables than in animal products.

Avidin is present in egg albumen and stable to heat and $\mathrm{pH}$ [23]. Avidin is a glycoprotein that binds biotin, creating one of the strongest non-covalent interactions in nature [131]. Biotin probably plays a role in the immune system because it is an enzyme cofactor in the tricarboxylic acid cycle and in the biosynthesis of fatty acids [132-134]. Avidin has been extensively used for biochemical assays, diagnosis, and drug delivery [135]. Recently, there has been growing interest in studying this avidin-biotin interaction in nanoscale drug delivery systems [131,136]. Korpela et al. [137] studied the binding of avidin to Gram-negative and -positive bacteria (Enterobacter cloacae, E. coli, B. cereus, P. aeruginosa, Serratia marcescens, Klebsiella pneumoniae, Streptococcus pyogenes, and Staphylococcus aureus and S. epidermidis). Avidin showed binding capacity to all the tested Gram-negative bacteria and to some Gram-positive. The E. coli K-12 avidin receptor was the outer membrane's porin protein (OmpFOmpC); these authors hypothesised that avidin traps biotin preventing its entry into the cell. Moreover, the avidin binding to the cell membrane may also imply a role in the mechanism of infection.

Ovotransferrin or conalbumin is another glycoprotein that also occurs in egg albumen and with inhibitory activity against both Gram-positive and -negative bacteria, and some yeasts [23,138-140]. Bacterial sensitivity to ovotransferrin varied among species, being E. coli, Pseudomonas, and Streptococcus mutans the most sensitive, and Staphylococcus aureus, Proteus, and Klebsiella the more resistant [138]. Although ovotransferrin's antimicrobial property is thought to be the result of its capacity to bind the iron used by the microorganisms for growth, recent studies suggest that its role is also iron independent $[138,139]$. Ovotransferrin properties imply applications such as ingredients for infant formula, food additive, or antimicrobial agent for animal health [139,141]. Furthermore, ovotransferrin has similarities to the homologous mammalian lactoferrin in terms of its protective roles, suggesting a "direct relationship between egg consumption and human health" [141].

Lysozyme is an enzyme found in egg white and milk, and even in blood [1,142-145]. Masschalck and Michiels [146] reviewed the properties against the microorganisms as well as the mode of action of lysozyme against Gram-positive and -negative bacteria, also providing insight into the causes of bacterial resistance. The antimicrobial capacities of lysozyme against bacteria are mainly due to its enzymic activity; lysozyme acts through peptidoglycan hydrolysis and cell lysis [1,143]. However, a new nonlytic activity has been shown by new findings [146,147]. As Gram-negative bacteria are resistant to lysozyme because of their outer membrane, different strategies were developed to extend 
its spectrum, including denaturation, modification (by attachment of polysaccharides, fatty acids, etc.), genetic modification, membrane permeabilizing agents (ethylenediaminetetraacetic acid, EDTA), and/or permeabilizing treatments such as high hydrostatic pressure treatments [146,148-155]. In order to study the role of the lysozyme enzymatic activity on its capacity against Gram-positive bacteria (S. aureus and Bacillus subtilis), Ibrahim et al. [148] constructed an inactive mutant of lysozyme. These authors revealed that the lysozyme activity against Gram-positive bacteria is independent of its muramidase activity; thus, the antibacterial action is due to structural factors.

\subsection{Polysaccharides}

Chitosan is produced commercially from chitin, a by-product obtained from exoskeletons of crustaceans and arthropods [1,23], with capacity to inhibit the growth of moulds and yeasts (Aspergillus flavus, Botrytis cinerea, Byssochlamys spp., Mucor racemosus, Rhizopus stolonifer, Saccharomyces cerevisiae, and Zygosaccharomyces bailii) and bacteria (E. coli, Lactobacillus fructivorans, L. monocytogenes, Salmonella, S. aureus, and Y. enterocolitica) from food [150,156-164]. Oh et al. [156] tested the antimicrobial activities of chitosan against food spoilage microorganisms in mayonnaise (Lactobacillus plantarum and L. fructivorans, Serratia liquefaciens, and Zygosaccharomyces bailii) founding an important decrease of the counts of L. fructivorans and Z. bailii at $25^{\circ} \mathrm{C}$. Roller and Covill [158] studied the use of chitosan ( $\left.3 \mathrm{~g} / \mathrm{L}\right)$ in mayonnaise with $0.16 \%$ of acetic acid or $1.2-2.6 \%$ of lemon juice and a population of ca. $5-6 \log \mathrm{CFU} / \mathrm{g}$ of S. enteritidis, Z. bailii, or L. fructivorans at 5 or $25^{\circ} \mathrm{C}$ for $8 \mathrm{~d}$; the results of these authors showed that chitosan with acetic acid could be used as a natural preservative under such conditions. Chitosan at a concentration of $0.005 \%$ combined with sodium benzoate $(0.025 \%)$ were synergic against yeasts (Saccharomyces exiguus, Saccharomycodes ludwigii and Torulaspora delbrueckii) in saline solutions [159]. Recently, chitosan's films with antimicrobials attached (garlic oil, sorbic acid, and nisin) to the polymer were used for packaging applications or in combination with ethanolic extract and polypropylene in order to contact the surface of the food; these films inhibited the growth of E. coli, Cronobacter sakazakii, Salmonella, Staphylococcus, L. monocytogenes, and B. cereus [150,158,165-171]. Sagoo et al. [159] and Devlieghere et al. [167] theorized that chitosan may interact with the cytoplasmic membrane's anionic polysaccharides and/or interfere the cell protein synthesis, both resulting in cell inhibition by altered permeability and/or compromised protein transport. The molecular weight of chitosan, its role as water binding agent and enzyme inhibitor, the improvement of membrane permeability, its activity as a bio-absorbent competing against bacteria nutrients, and its capacity to bind to DNA and inhibit the synthesis of mRNA and proteins have been reported [163,172-179].

\subsection{Lipids}

Food lipids may inhibit the proliferation of microorganisms [1], e.g., those present in milk can inhibit Gram-positive and -negative bacteria, and fungi [180-185]. The activity of triglycerides and lipids from bovine milk was investigated against E. coli O157:H7, S. enteritidis, Campylobacter jejuni, L. monocytogenes, and Clostridium perfringens by Sprong et al. [180]. C10:0 and C12:0 fatty acids and sphingolipids showed bactericidal activity, whereas phosphoglycerides were moderately bactericidal. These authors [181] also studied the activity of sphingolipids combined with C10:0 and C12:0 fatty acids, and unsaturated C18 fatty acids; L. monocytogenes and Campylobacter jejuni were very sensitive, whereas E. coli O157:H7 and S. enteritidis were less vulnerable. Eicosapentaenoic acid and docosahexaenoic acid, two fatty acids from animal origin, can inhibit the growth of bacteria [186-188]. The knowledge about their mode of action is limited; their first action is the electron transport chain's disruption and the cell membrane's oxidative phosphorylation [188]. Furthermore, the mechanism of action also implies the inhibition of the enzymatic activity by the cell, the damage of the nutrient uptake, or peroxidation. The combination of fatty acids and monoglycerides was studied showing an increase in the antimicrobial activity [1]. Their broad spectrum of activity makes them very useful as agents against microorganisms for various applications in food safety increasing food quality through its preservation [188]. 


\section{Natural Antimicrobials from Bacteria and Viruses: Biopreservation}

Biopreservation is defined as "the use of microorganisms (including bacteriophages), their metabolic products, or both to preserve foods that are not generally considered fermented" [189].

\subsection{Controlled Acidification}

The production of acid by lactic acid bacteria (LAB) under controlled acidification conditions is a preservation form very important in food production; the $\mathrm{pH}$ of the food, the characteristics of the targeted microorganism, the fermented carbohydrate that is going to be used by the biopreservatives, the LAB growth kinetics, the temperature (refrigeration or abuse), and the targeted pathogens are factors to be taken into account [189]. The use of LAB for biopreservation comes back to the 1950s for preventing the production of botulinum toxin [190-192]; Clostridium botulinum is unable to grow at $\mathrm{pH}<4.6$, so LAB is added to the food for acid production after the use of a fermentable carbohydrate also added to it and, consequently, the $\mathrm{pH}$ decreases [190,193]. Hutton and Chehak [193] described the "Wisconsin process" (lactic acid starter culture combined with sucrose) as a similar method to be applied in bacon with a reduced content of nitrite. These authors also found a similar effect with the combination of Pediococcus acidilactici plus dextrose in chicken salad; it was interesting to report that conditions of abuse temperature were the most effective for the production of acid by P. acidilactici after the use of dextrose.

\subsection{Bacteriocins}

Some lactic acid bacteria produce ribosomally synthesized peptides, called bacteriocins, with antimicrobial capacity that are not lethal to the host; these proteins inhibit both pathogenic and spoilage bacteria without changing the physicochemical characteristics of the food, that is, the inhibition is not exerted by acidification, protein denaturation, or other processes [189,194-204]. The interest in LAB-produced bacteriocins has grown dramatically because of their antimicrobial capacities and the use of LAB as starter cultures [198]. The use of bacteriocins or bacteriocinogenic LAB or both is important to the food industry because of the demand for natural products by consumers that are also increasing concern about foodborne pathogens [189].

Gram-positive bacteria are inhibited by most bacteriocins. Gram-negative bacteria can be increasingly sensitive to bacteriocins after the use of chelating agents or hydrostatic pressure $[205,206]$; these techniques can also be synergic enhancing the action of bacteriocins against Gram-positive bacteria $[189,207]$, or even with the use of nanoparticles [208,209] or nanovesicles [210].

Bacteriocins can be used in different ways in foods [189]: (i) They can be directly added to foods inhibiting the growth of both pathogenic and spoilage bacteria; nisin is the only bacteriocin commercially available. Nisin is added to milk, cheese, canned foods, mayonnaise, and other foods. It is considered as a Generally Recognized as Safe (GRAS) food preservative, and once it is absorbed onto surfaces it inhibits the growth of Listeria spp. and prevents the formation of biofilms [211-216]. Pediocins also inhibit the growth of L. monocytogenes and they are used in salads and salad dressings, cream, cheese and meats [216-225]. Reuterin is secreted by Lactobacillus reuteri and possess activity against Gram-positive and -negative pathogenic bacteria [226,227]. (ii) To add bacteriocin-producing bacteria to non-fermented foods or use them as starter cultures for the improvement of food safety. For a fine description see Montville and Chikindas [189]. Natamycin is produced by fermentation using Streptomyces spp. acting against foodborne moulds and yeasts; however, it is inactive against bacteria and viruses [1,228]. (iii) A third way is to use bacteriocin-producing bacteria as starter cultures to direct the fermentation. The benefits of defined starter cultures depend on their capacity to predominate over the indigenous microbiota [229-233].

An increasing problem is resistance to bacteriocins. The emergence of pathogens resistant to bacteriocins can undermine their use as antimicrobial agents. For example, nisin-resistant isolates have been generated from C. botulinum, L. monocytogenes, S. aureus, and Bacillus licheniformis, B. subtilis, and 
B. cereus [234-238]. Ming and Daeschel [234] evaluated Gram-positive pathogenic and food spoilage bacteria for their resistance to nisin obtaining a L. monocytogenes mutant (resistant to nisin at $2000 \mathrm{U} / \mathrm{mL}$ ). The resistant mutant had straight-chain fatty acids at a higher percentage, and less percentage of branched-chain fatty acids; thus, both the cell membrane structure and function suffered changes as a resistance response to nisin. Turovskiy et al. [235] investigated the quorum sensing mediated by the autoinducer AI-2 as a mechanism for triggering the stress response in L. monocytogenes; thus, they examined the acquisition of resistance to nisin and lactic acid by the microorganism. After pre-exposing the cells to the autoinducer and being challenged with specific stresses, the resistance to nisin and lactic acid was not mediated through quorum sensing. The frequencies of colony formation on agar media with different concentrations of nisin by different strains of Clostridium botulinum were determined by Mazzotta et al. [236]. Increasing concentrations of nisin generated resistant isolates, and the cells' nisin resistance was maintained by their spores. Naghmouchi et al. [237] developed variants of Listeria monocytogenes resistant to pediocin PA-1, divergicin M35, and nisins A and Z. These authors reported that the resistance decreased antibiotic sensitivity to ampicillin, chloramphenicol, erythromycin, and tetracycline. Laursen et al. [238] studied if the exposure to a Lactobacillus plantarum pediocin could lead to resistance in L. monocytogenes. These authors observed changes in the expression of genes regulated by the LisRK system and the SigB and SigL sigma factors; thus, a single exposure to a sublethal concentration of the bacteriocin initiates a response leading to resistance. Some authors have suggested the use of bacteriocin mixtures to overcome the problem of resistance $[239,240]$ although this method is effective only when different mechanisms of resistance are implicated [189]. Cross-resistance among bacteriocins have been observed [237,241-244] complicating the situation. The stability of Listeria monocytogenes mutant's resistance to LAB bacteriocins (mesenterocin, curvaticin, and plantaricin) was estimated by Rekhif et al. [241] who found that it was maintained for several generations even when the bacteriocins were not present. Furthermore, the mutants resistant to one of the bacteriocins showed a cross-resistance to the two other bacteriocins, but not to nisin. Nisin-resistant variants of Listeria monocytogenes as well as resistant to pediocin produced by Pediococcus pentosaceus 34, and enterocin produced by Enterococcus faecium FH99 were developed by Kaur et al. [242,243]. Cross-resistance between pediocin 34 and enterocin FH 99 was found, but not with nisin. The understanding of bacteriocin resistance is incomplete and further investigations are needed.

\subsection{Bacteriophages}

Bacteriophages are viruses whose only hosts are bacteria [245-247]. The addition of virulence factors to the host has been reported, although reductions in virulence have been also described [248] with potential consequences in phage therapy.

Bacteriophages are consumed with the diet because they are natural components of food microbiota $[189,249]$. The use of bacteriophages to control foodborne bacteria is characterized by the low numbers of non-growing pathogens together with large populations of indigenous bacteria [250-255]. Moreover, the repeated use of bacteriophages in food could create resistance [189,256]. The complexity of this issue caused Montville and Chikindas [189] to conclude that "like bacteriocins, bacteriophages are not silver bullets but need to be used from a perspective that considers the microbial ecology of the food".

\section{Natural Antimicrobials from Algae and Mushrooms}

Macroalgae (seaweeds) and microalgae (diatoms) produce substances with antimicrobial activity. Pharmaceutical and food industries search for promising marine algae derivatives [257-259]. There is limited research to evaluate the antimicrobial activity of algae in food biopreservation.

Several authors have studied the antimicrobial characteristics of algae. Herrero et al. [260] carried out the screening for this type of compounds in a macro- and a micro-algae (Himanthalia elongata and Synechocystis spp., respectively); extracts from both had antioxidant capacities and antimicrobial action against $S$. aureus and E. coli. Similar results were obtained by Devi et al. [261] when they studied 
extracts from Haligra spp. active against S. aureus. Hymanthalia elongata, Saccharina latissima, Laminaria digitate, Padina, and Dictyota were reported to have antimicrobial activity against L. monocytogenes, Salmonella, Enterococcus faecalis, P. aeruginosa, B. cereus, and E. coli [262,263].

Algae-derived compounds such as carrageenan and alginates are useful for food coatings and films; these compounds together with other natural antimicrobials will enhance their applications [264]. Carrageenan and alginates have been used in a variety of ways in food industry: forming nanocomposite films enriched with essential oils enhancing its effectiveness against L. monocytogenes [265], combined with chitosan and isothiocyanate in a film used for food packaging and active against C. jejuni [266], or combined with EDTA in a film increasing the potential to reduce Salmonella populations [267]. Alboofetileh et al. [265] developed nanocomposite films with antimicrobial characteristics to control the growth of foodborne pathogens. Firstly, they tested the antibacterial effects of the essential oils of caraway, cinnamon, clove, coriander, cumin, and marjoram against E. coli, S. aureus, and L. monocytogenes. Then, the essential oils of marjoram, clove, and cinnamon-the most potent against the microorganisms - were incorporated into nanocomposite films made with alginate or clay and tested for $12 \mathrm{~d}$. Marjoram (1.5\%) showed the highest activity against microorganisms in all matrices decreasing the populations of the three microorganisms up to $6.3,4.5$, and $5.8 \log$, respectively. Four Campylobacter jejuni strains were tested with allyl isothiocyanate contained into an edible coating (with $0.2 \% \mathrm{~K}$-carrageenan and $2 \%$ chitosan) on vacuum-packaged chicken breasts at $4{ }^{\circ} \mathrm{C}$ [266]; the coatings with 50 or $100 \mu \mathrm{L} / \mathrm{g}$ of allyl isothiocyanate reduced the number of cells of the microorganism to levels below the detection limit after $5 \mathrm{~d}$. Olaimat and Holley [267] tested the same carrageenan/chitosan coating previously described for its ability to inhibit the population of Salmonella on fresh chicken breasts; the edible coating contained allyl isothiocyanate, mustard, EDTA or their combinations. Coatings containing $50 \mu \mathrm{L} / \mathrm{g}$ of allyl isothiocyanate or $250 \mathrm{mg} / \mathrm{g}$ of mustard reduced Salmonella's counts about $2.3 \log \mathrm{CFU} / \mathrm{g}$ at $4{ }^{\circ} \mathrm{C}$ after $21 \mathrm{~d}$; LAB was also reduced.

Among fungi, mushrooms have antimicrobial and antioxidant capacities [2]. Wild Laetiporus sulphureus (Bull.) Murrill fruiting bodies extracts have shown antimicrobial activity in vitro against bacteria such as Candida albicans, Candida parapsilopsis, E. coli, S. aureus, Enterococcus faecalis, and S. epidermidis. Antimicrobial activity was also detected by edible mushrooms extracts of Aphyllophorales [268], Agaricus [269], and Armillaria mellea, Meripilus giganteus, Morchella costata and M. elata, M. esculenta var. vulgaris, M. hortensis, M. rotunda, Paxillus involutus, and Pleurotus eryngii and P. ostreatus [270]. Methanolic extracts of 6 wild edible mushrooms (Cantharellus cibarius, Clavaria vermiculris, Lycoperdon perlatum, Marasmius oreades, Pleurotus pulmonarius, and Ramaria formosa) were used by Ramesh and Pattar [268]. All the isolates showed high content of phenols and flavonoids with antimicrobial activity against several of pathogenic bacteria (E. coli, B. subtilis, P. aeruginosa, and S. aureus) and fungi (Candida albicans) indicating that the concentrations of the components directly influence the capability of the isolated mushrooms against the microorganisms. Öztürk et al. [269] investigated the fatty acids from Agaricus essettei, A. bitorquis and A. bisporus extracts founding that linoleic and palmitic acids were dominant and active against Gram-positive bacteria (Micrococcus luteus, Micrococcus flavus, Bacillus subtilis, and Bacillus cereus). Kalyoncu et al. [270] determined the antimicrobial activities of ethanol extracts from the mushrooms cited above against 11 microorganisms (Bacillus cereus and Bacillus subtilis, E. coli, Enterobacter aerogenes and E. cloacae, Enterococcus faecalis, Proteus vulgaris, S. typhimurium, Sarcina lutea, S. aureus, and the yeast Candida albicans). P. ostreatus and M. giganteus were the species with the greater activity against both bacteria and yeast.

Mushrooms' antimicrobials have not been sufficiently investigated to date for their food application. A fine review of them can be found in Gyawali and Ibrahim [2]. Further information can be found in References [271-274]. 


\section{Future Perspectives}

The food industry is receiving increasing pressure from consumers for the use of natural components in its products. The major objective is to use them as natural antimicrobials, and three methods are the most promising in food systems.

\subsection{Direct Application on Food}

The use of natural antimicrobials in food as biopreservatives is often limited due to the smell and taste given to the foods and the difficulties for achieving a good solubility in them [2,275]. Antimicrobial activity against $B$. cereus in rice has been demonstrated after the inclusion of basil, thyme, or oregano essential oils [43,276,277]; $1 \%$ of fresh garlic was active against E. coli $\mathrm{O} 157$ and S. enterica serovar Enteritidis in mayonnaise [37]; inhibitory activity against L. monocytogenes was found with ground cinnamon in pasteurized apple juice [278] and with essential oils of cinnamon, bark, and clove in semi-skimmed milk [279]; the essential oils of clove, cinnamon, thyme, and bay were active against L. monocytogenes in cheese $[280,281]$; thyme, oregano and lemongrass essential oils combined with modified atmosphere packaging were used to evaluate the inhibition of the total mesophilic population in cabbage and radish sprouts resulting in almost total inhibition of the microorganisms [282].

The shelf-life of meat and meat products has been improved using extracts or essential oils of natural antimicrobials compounds. Thyme and oregano essential oils at $0.1-0.3 \%$ were active against meat-based products dipped in them and combined with modified atmosphere packaging [283]. Thyme essential oil combined with nisin significantly decreased the population of L. monocytogenes [284] and E. coli O157:H7 [285] in minced beef meat under refrigeration conditions. C. jejuni populations were reduced in chicken meat after the application of rosemary extracts combined with a pre-freezing period [286] or after the use of Inula graveolens, Laurus nobilis, Satureja montana, and Pistacia lentiscus essential oils combined with packaging under microaerophilic conditions [287].

\subsection{Edible Films and Coatings for Packaging}

Food-packaging related industries are showing interest in the use of natural antimicrobials in edible films and coatings to improve food quality. At the same time, consumers' concerns created by plastic packaging are reduced. Lysozyme-chitosan composite films (a $2 \%$ chitosan film with an incorporated solution of $10 \%$ lysozyme at $0,20,60$, or 100\%) were developed by Park et al. [150] for improving the antibacterial capacities of chitosan films. The efficacy of chitosan films was enhanced with 60\% lysozyme against both Streptococcus faecalis (reduction of $3.8 \mathrm{log}$ cycles) and Escherichia coli (reductions of $2.7 \mathrm{log}$ cycles). Bayarri et al. [153] determined the properties of lysozyme with methoxyl pectin for developing an edible film with antimicrobial activity. The formation of these complexes considerably decrease the lysozyme antimicrobial activity; however, after their use to manufacture an edible antimicrobial film, the lysozyme release was controlled and the enhancement of the lysozyme release was reported, allowing the use of the edible film to protect foods against microorganisms sensible to lysozyme activity. In their study, Güçbilmez et al. [154] incorporated lysozyme into zein films together with chickpea albumin, bovine serum albumin, and EDTA; that combination gave zein films effective activity against $E$. coli and Bacillus subtilis. Chitosan was combined with sodium caseinate to create films by Moreira et al. [162]; these authors evaluated their effectiveness against microbiota of cheese, salami, and carrots. Assays with the film-forming solutions applied on foods showed a significant antimicrobial action on the mesophilic, psychrotrophic, and yeasts and moulds populations with reductions of about $2.0-4.5 \log \mathrm{CFU} / \mathrm{g}$.

Edible films containing different extracts or essentials oils have shown their efficacy against foodborne pathogens such as E. coli O157:H7 [288-290], L. monocytogenes, and Salmonella [289,290]. Jang et al. [288] manufactured an edible film for strawberries containing $10 \%$ of grapefruit seed extract. The film inhibited the growth of E. coli O157:H7 and L. monocytogenes, and the populations of aerobic bacteria, yeast and moulds decreased after $14 \mathrm{~d}$ of storage. Ready-to-eat minimally processed salads 
were packaged under modified atmosphere conditions with films of polypropylene plus ethylene-vinyl alcohol copolymer (with a 29\% ethylene molar content) containing oregano and citral [289,290]. The results showed that antimicrobial activity reduced spoilage microbiota on the salad as well as inhibit the growth of E. coli, S. enterica, and L. monocytogenes; the inhibition was greater against Gram-negative bacteria. Chitosan-based films have been very effective in increasing the shelf-life of different products such as fruits and vegetables [291-296], and different meats and products [297-300]. Cé et al. [291] reported the increase in activity against several bacteria in minimally processed pear after the addition of nisin and peptide P34 to chitosan films: E. coli, B. cereus, Clostridium perfringens, Lactobacillus acidophilus, L. monocytogenes, S. aureus, S. enteritidis, Aspergillus phoenicis, and Penicillium stoloniferum. Films containing natamycin showed similar inhibition than those with chitosan alone. Vodnar et al. [297] developed chitosan-based films with bioactive compounds from green and black teas for the control of L. monocytogenes on vacuum-packaged ham steak at $20{ }^{\circ} \mathrm{C}$ for $10 \mathrm{~d}$ and $4{ }^{\circ} \mathrm{C}$ for 8 weeks. L. monocytogenes growth was inhibited in a dose-dependent manner: $4 \%$ of green tea extract was the most effective at both temperatures; $2 \%$ of green tea or $2 \%$ and $4 \%$ of black tea showed less antibacterial activity. Chitosan lactate was included into low-density polyethylene [298]; these films were applied on the surfaces of red meat and tested against E. coli, L. monocytogenes, and S. enteritidis. The microorganisms on the meat surface were not inhibited; however, a significant extension of the red colour shelf-life was observed. Soy protein edible films with EDTA or nisin have been studied for their physical and antimicrobial properties [301]; the films incorporated with 1\% of grape seed extract, $10,000 \mathrm{IU} / \mathrm{g}$ of nisin, and $0.16 \%$ of EDTA showed the greatest activity against L. monocytogenes reducing its population by approximately $3 \log$ CFU/mL. E. coli O157:H7 and S. typhimurium counts were reduced by approximately 2 and $1 \log \mathrm{CFU} / \mathrm{mL}$, respectively.

\subsection{Nanoparticles and Nanovesicles}

Nanotechnology is increasing its role in the food industry and some studies have been carried out over the last years. Applications of nanotechnology to deliver natural antimicrobial compounds in foods are very limited because of the complexity of the technology needed and the food matrix. Eby et al. [149] reported that hen egg-white lysozyme catalyzed the formation of silver nanoparticles that were able to maintain the hydrolase function of the enzyme; they were effective against $E$. coli, Bacillus anthracis, S. aureus, and Candida albicans. These nanoparticles had strong activity against silver-resistant strains of Proteus mirabilis as well as against an antibiotic- and silver-resistant E. coli strain. Human epidermal keratinocytes studies showed that these nanoparticles were non-toxic at the concentrations used to inhibit microbial growth. Nisin nanoparticles have been tested against L. monocytogenes and S. aureus with good results [302-304], as well as bacteriocin nanovesicles [210] or nanoparticles [208,209] against different pathogens. Zou et al. [302] evaluated the prolonged antimicrobial stability of liposome nanoparticles loaded with nisin against L. monocytogenes and S. aureus. The MIC of the nanoparticles against both microorganisms was $320 \mathrm{UI} / \mathrm{mL}$, reducing their populations by more than $6 \log$ CFU/mL after 48 and $72 \mathrm{~h}$ of incubation, respectively. Field et al. [303] identified a nisin A variant with a serine to glycine change at position 29 and with enhanced efficacy against $S$. aureus. Three more derivatives were developed and tested against E. coli, Cronobacter sakazakii, and S. enterica serovar Typhimurium showing enhanced antimicrobial activity. Encapsulation provides stability to bacteriocins; thus, de Mello et al. [210] encapsulated the peptide pediocin in nanovesicles of soybean phosphatidylcholine. The nanovesicles maintained $50 \%$ of the pediocin antimicrobial activity for $13 \mathrm{~d}$ at $4{ }^{\circ} \mathrm{C}$ against Listeria monocytogenes, L. innocua, and L. ivanovii. Gold nanoparticles with Lactobacillus acidophilus CH1 bacteriocin were used by Mossallam et al. [208] against intestinal microsporidiosis in immunosuppressed mice. The anti-microsporidia activity of the bacteriocin was potentiated, showing a sustained reduction in faecal spore shedding and intestinal spore load. 


\section{Conclusions}

Since consumers increasingly demand food free of synthetic preservatives, it is necessary to identify and study new alternatives. These new approaches should be useful for controlling foodborne pathogens and for extending the foods' shelf-life. From the economic point of view, the search for natural antimicrobials must be cost-effective, and one alternative approach would be the mixture of several natural antimicrobials combined with food preservation techniques.

Due to the complexity of food matrices, natural antimicrobial compounds could bind with some food components limiting their action. Nanoparticles and/or nanovesicles have enormous potential in food safety as an effective antimicrobial delivery system, although this technology has raised concerns over consumers' safety. Therefore, further research is needed to determine the best antimicrobial delivery technology and the best concentrations of such natural antimicrobial compounds.

Author Contributions: All authors contributed equally to the writing and revision of the final version.

Funding: The I+D+I Program, Consejería de Sanidad, Junta de Castilla y León, Spain, financially supported this work (SAN196/VA07/07, SAN673/VA05/08, SAN126/09).

Conflicts of Interest: The authors declare no conflicts of interest.

\section{References}

1. Pisoschi, A.M.; Pop, A.; Georgescu, C.; Turcuş, V.; Olah, N.K.; Mathe, E. An overview of natural antimicrobials role in food. Eur. J. Med. Chem. 2018, 143, 922-935. [CrossRef] [PubMed]

2. Gyawali, R.; Ibrahim, S.A. Natural products as antimicrobial agents. Food Control 2014, 46, 412-429. [CrossRef]

3. Dorman, H.J.D.; Deans, S.G. Antimicrobial agents from plants: antibacterial activity of plant volatile oils. J. Appl. Microbiol. 2000, 88, 308-316. [CrossRef] [PubMed]

4. Lee, N.-K.; Paik, H.-D. Status, antimicrobial mechanism, and regulation of natural preservatives in livestock food systems. Korean J. Food Sci. Anim. Resour. 2016, 36, 547-557. [CrossRef]

5. Aziz, M.; Karboune, S. Natural antimicrobial/antioxidant agents in meat and poultry products as well as fruits and vegetables: A review. Crit. Rev. Food Sci. Nutr. 2018, 58, 486-511. [CrossRef]

6. Hygreeva, D.; Pandey, M.C.; Radhakrishna, K. Potential applications of plant based derivatives as fat replacers, antioxidants and antimicrobials in fresh and processed meat products. Meat Sci. 2014, 98, 47-57. [CrossRef]

7. Burt, S.A.; Reinders, R.D. Antibacterial activity of selected plant essential oils against Escherichia coli O157:H7. Lett. Appl. Microbiol. 2003, 36, 162-167. [CrossRef]

8. Gonelimali, F.D.; Lin, J.; Miao, W.; Xuan, J.; Charles, F.; Chen, M.; Hatab, S.R. Antimicrobial properties and mechanism of action of some plant extracts against food pathogens and spoilage microorganisms. Front. Microbiol. 2018, 9, 1-9. [CrossRef]

9. Tajkarimi, M.M.; Ibrahim, S.A.; Cliver, D.O. Antimicrobial herb and spice compounds in food. Food Control 2010, 21, 1199-1218. [CrossRef]

10. Cueva, C.; Moreno-Arribas, M.V.; Martín-Álvarez, P.J.; Bills, G.; Vicente, M.F.; Basilio, A.; Rivas, C.L.; Requena, T.; Rodríguez, J.M.; Bartolomé, B. Antimicrobial activity of phenolic acids against commensal, probiotic and pathogenic bacteria. Res. Microbiol. 2010, 161, 372-382. [CrossRef]

11. Negi, P.S. Plant extracts for the control of bacterial growth: Efficacy, stability and safety issues for food application. Int. J. Food Microbiol. 2012, 156, 7-17. [CrossRef] [PubMed]

12. Savoia, D. Plant-derived antimicrobial compounds: alternatives to antibiotics. Future Microbiol. 2012, 7, 979-990. [CrossRef] [PubMed]

13. Mendonca, A.; Jackson-Davis, A.; Moutiq, R.; Thomas-Popo, E. Use of natural antimicrobials of plant origin to improve the microbiological safety of foods. In Food and Feed Safety Systems and Analysis; Elsevier: Amsterdam, The Netherlands, 2018; pp. 249-272. ISBN 9780128498880.

14. Gutierrez, J.; Barry-Ryan, C.; Bourke, P. The antimicrobial efficacy of plant essential oil combinations and interactions with food ingredients. Int. J. Food Microbiol. 2008, 124, 91-97. [CrossRef] [PubMed] 
15. Proestos, C.; Boziaris, I.S.; Kapsokefalou, M.; Komaitis, M. Natural antioxidant constituents from selected aromatic plants and their antimicrobial activity against selected pathogenic microorganisms. In Proceedings of the Food Technology and Biotechnology, Osijek, Croatia, 17-20 September 2008; Volume 46, pp. 151-156.

16. Holley, R.A.; Patel, D. Improvement in shelf-life and safety of perishable foods by plant essential oils and smoke antimicrobials. Food Microbiol. 2005, 22, 273-292. [CrossRef]

17. Nanasombat, S.; Lohasupthawee, P. Antibacterial activity of crude ethanolic extracts and essential oils of spices against Salmonella and other Enterobacteria. KMITL Sci. Technol. J. 2005, 5, 527-538.

18. Conner, D.E.; Beuchat, L.R.; Worthington, R.E.; Hitchcock, H.L. Effects of essential oils and oleoresins of plants on ethanol production, respiration and sporulation of yeasts. Int. J. Food Microbiol. 1984, 1, 63-74. [CrossRef]

19. González-Fandos, E.; García-López, M.L.; Sierra, M.L.; Otero, A. Staphylococcal growth and enterotoxins (A-D) and thermonuclease synthesis in the presence of dehydrated garlic. J. Appl. Bacteriol. 1994, 77, 549-552. [CrossRef]

20. Cavallito, C.J.; Bailey, J.H. Allicin, the antibacterial principle of Allium sativum. I. Isolation, physical properties and antibacterial action. J. Am. Chem. Soc. 1944, 66, 1950-1951. [CrossRef]

21. Wills, E.D. Enzyme inhibition by allicin, the active principle of garlic. Biochem. J. 1956, 63, 514-520. [CrossRef]

22. Barone, F.E.; Tansey, M.R. Isolation, purification, identification, synthesis, and kinetics of activity of the anticandidal component of Allium sativum, and a hypothesis for its mode of action. Mycologia 1977, 69, 793. [CrossRef]

23. Taylor, T.M.; Davidson, P.M. Chemical preservatives and natural antimicrobial compounds. In Food Microbiology: Fundamentals and Frontiers, 3rd ed.; American Society of Microbiology: Washington, DC, USA, 2014; pp. 713-745.

24. Kim, J.W.; KIM, Y.S.; Kyung, K.H. Inhibitory activity of essential oils of garlic and onion against bacteria and yeasts. J. Food Prot. 2004, 67, 499-504. [CrossRef] [PubMed]

25. Ceylan, E.; Fung, D.Y.C.; Sabah, J.R. Antimicrobial activity and synergistic effect of cinnamon with sodium benzoate or potassium sorbate in controlling Escherichia coli O157:H7 in apple juice. J. Food Sci. 2004, 69, FMS102-FMS106. [CrossRef]

26. Daferera, D.J.; Ziogas, B.N.; Polissiou, M.G. GC-MS analysis of essential oils from some greek aromatic plants and their fungitoxicity on Penicillium digitatum. J. Agric. Food Chem. 2000, 48, 2576-2581. [CrossRef]

27. Filoche, S.K.; Soma, K.; Sissons, C.H. Antimicrobial effects of essential oils in combination with chlorhexidine digluconate. Oral Microbiol. Immunol. 2005, 20, 221-225. [CrossRef]

28. Friedman, M.; Henika, P.R.; Mandrell, R.E. Bactericidal activities of plant essential oils and some of their isolated constituents against Campylobacter jejuni, Escherichia coli, Listeria monocytogenes, and Salmonella enterica. J. Food Prot. 2002, 65, 1545-1560. [CrossRef]

29. Gill, A.O.; Holley, R.A. Mechanisms of bactericidal action of cinnamaldehyde against Listeria monocytogenes and of eugenol against L. monocytogenes and Lactobacillus sakei. Appl. Environ. Microbiol. 2004, 70, 5750-5755. [CrossRef]

30. Nielsen, P.V.; Rios, R. Inhibition of fungal growth on bread by volatile components from spices and herbs, and the possible application in active packaging, with special emphasis on mustard essential oil. Int. J. Food Microbiol. 2000, 60, 219-229. [CrossRef]

31. Smith-Palmer, A. Influence of subinhibitory concentrations of plant essential oils on the production of enterotoxins A and B and -toxin by Staphylococcus aureus. J. Med. Microbiol. 2004, 53, 1023-1027. [CrossRef]

32. Moreira, M.R.; Ponce, A.; del Valle, C.E.; Roura, S.I. Inhibitory parameters of essential oils to reduce a foodborne pathogen. LWT Food Sci. Technol. 2005, 38, 565-570. [CrossRef]

33. Mytle, N.; Anderson, G.L.; Doyle, M.P.; Smith, M.A. Antimicrobial activity of clove (Syzgium aromaticum) oil in inhibiting Listeria monocytogenes on chicken frankfurters. Food Control 2006, 17, 102-107. [CrossRef]

34. Bagamboula, C.F.; Uyttendaele, M.; Debevere, J. Antimicrobial effect of spices and herbs on Shigella sonnei and Shigella flexneri. J. Food Prot. 2003, 66, 668-673. [CrossRef] [PubMed]

35. Bennis, S.; Chami, F.; Chami, N.; Bouchikhi, T.; Remmal, A. Surface alteration of Saccharomyces cerevisiae induced by thymol and eugenol. Lett. Appl. Microbiol. 2004, 38, 454-458. [CrossRef] [PubMed]

36. Gaysinsky, S.; Davidson, P.M.; Bruce, B.D.; Weiss, J. Stability and antimicrobial efficiency of eugenol encapsulated in surfactant micelles as affected by temperature and pH. J. Food Prot. 2005, 68, 1359-1366. [CrossRef] [PubMed] 
37. Leuschner, R.G.K.; Zamparini, J. Effects of spices on growth and survival of Escherichia coli 0157 and Salmonella enterica serovar Enteritidis in broth model systems and mayonnaise. Food Control 2002, 13, 399-404. [CrossRef]

38. López-Malo, A.; Alzamora, S.M.; Palou, E. Aspergillus flavus dose-response curves to selected natural and synthetic antimicrobials. Int. J. Food Microbiol. 2002, 73, 213-218. [CrossRef]

39. López-Malo, A.; Maris Alzamora, S.; Palou, E. Aspergillus flavus growth in the presence of chemical preservatives and naturally occurring antimicrobial compounds. Int. J. Food Microbiol. 2005, 99, 119-128. [CrossRef]

40. Rhayour, K.; Bouchikhi, T.; Tantaoui-Elaraki, A.; Sendide, K.; Remmal, A. The mechanism of bactericidal action of oregano and clove essential oils and of their phenolic major components on Escherichia coli and Bacillus subtilis. J. Essent. Oil Res. 2003, 15, 286-292. [CrossRef]

41. Seaberg, A.C.; Labbe, R.G.; Shetty, K. Inhibition of Listeria monocytogenes by elite clonal extracts of oregano (Origanum vulgare). Food Biotechnol. 2003, 17, 129-149. [CrossRef]

42. Singh, A.; Singh, R.K.; Bhunia, A.K.; Singh, N. Efficacy of plant essential oils as antimicrobial agents against Listeria monocytogenes in hotdogs. LWT Food Sci. Technol. 2003, 36, 787-794. [CrossRef]

43. Ultee, A.; Smid, E. Influence of carvacrol on growth and toxin production by Bacillus cereus. Int. J. Food Microbiol. 2001, 64, 373-378. [CrossRef]

44. Burt, S. Essential oils: their antibacterial properties and potential applications in foods-A review. Int. J. Food Microbiol. 2004, 94, 223-253. [CrossRef] [PubMed]

45. Burt, S.A.; Vlielander, R.; Haagsman, H.P.; Veldhuizen, E.J.A. Increase in activity of essential oil components carvacrol and thymol against Escherichia coli O157:H7 by addition of food stabilizers. J. Food Prot. 2005, 68, 919-926. [CrossRef] [PubMed]

46. Di Pasqua, R.; De Feo, V.; Villani, F.; Mauriello, G. In vitro antimicrobial activity of essential oils from Mediterranean Apiaceae, Verbenaceae and Lamiaceae against foodborne pathogens and spoilage bacteria. Ann. Microbiol. 2005, 55, 139-143.

47. Kiskó, G.; Roller, S. Carvacrol and p-cymene inactivate Escherichia coli O157:H7 in apple juice. BMC Microbiol. 2005, 5, 36. [CrossRef]

48. Olasupo, N.A.; Fitzgerald, D.J.; Gasson, M.J.; Narbad, A. Activity of natural antimicrobial compounds against Escherichia coli and Salmonella enterica serovar Typhimurium. Lett. Appl. Microbiol. 2003, 37, 448-451. [CrossRef]

49. Olasupo, N.A.; Fitzgerald, D.J.; Narbad, A.; Gasson, M.J. Inhibition of Bacillus subtilis and Listeria innocua by nisin in combination with some naturally occurring organic compounds. J. Food Prot. 2004, 67, 596-600. [CrossRef]

50. Özkan, G.; Sağdiç, O.; Özcan, M. Note: Inhibition of pathogenic bacteria by essential oils at different concentrations. Food Sci. Technol. Int. 2003, 9, 85-88. [CrossRef]

51. Penalver, P.; Huerta, B.; Borge, C.; Astorga, R.; Romero, R.; Perea, A. Antimicrobial activity of five essential oils against origin strains of the Enterobacteriaceae family. APMIS 2005, 113, 1-6. [CrossRef]

52. Aligiannis, N.; Kalpoutzakis, E.; Mitaku, S.; Chinou, I.B. Composition and antimicrobial activity of the essential oils of two Origanum species. J. Agric. Food Chem. 2001, 49, 4168-4170. [CrossRef]

53. Chami, N.; Bennis, S.; Chami, F.; Aboussekhra, A.; Remmal, A. Study of anticandidal activity of carvacrol and eugenol in vitro and in vivo. Oral Microbiol. Immunol. 2005, 20, 106-111. [CrossRef]

54. Elgayyar, M.; Draughon, F.A.; Golden, D.A.; Mount, J.R. Antimicrobial activity of essential oils from plants against selected pathogenic and saprophytic microorganisms. J. Food Prot. 2001, 64, 1019-1024. [CrossRef] [PubMed]

55. Falcone, P.; Speranza, B.; Del Nobile, M.A.; Corbo, M.R.; Sinigaglia, M. A study on the antimicrobial activity of thymol intended as a natural preservative. J. Food Prot. 2005, 68, 1664-1670. [CrossRef] [PubMed]

56. Lambert, R.J.W.; Skandamis, P.N.; Coote, P.J.; Nychas, G.-J.E. A study of the minimum inhibitory concentration and mode of action of oregano essential oil, thymol and carvacrol. J. Appl. Microbiol. 2001, 91, 453-462. [CrossRef] [PubMed]

57. Manohar, V.; Ingram, C.; Gray, J.; Talpur, N.A.; Echard, B.W.; Bagchi, D.; Preuss, H.G. Antifungal activities of origanum oil against Candida albicans. Mol. Cell. Biochem. 2001, 228, 111-117. [CrossRef]

58. Rota, C.; Carramiñana, J.J.; Burillo, J.; Herrera, A. In vitro antimicrobial activity of essential oils from aromatic plants against selected foodborne pathogens. J. Food Prot. 2004, 67, 1252-1256. [CrossRef] 
59. Sacchetti, G.; Maietti, S.; Muzzoli, M.; Scaglianti, M.; Manfredini, S.; Radice, M.; Bruni, R. Comparative evaluation of 11 essential oils of different origin as functional antioxidants, antiradicals and antimicrobials in foods. Food Chem. 2005, 91, 621-632. [CrossRef]

60. Tiwari, B.K.; Valdramidis, V.P.; O’ Donnell, C.P.; Muthukumarappan, K.; Bourke, P.; Cullen, P.J. Application of natural antimicrobials for food preservation. J. Agric. Food Chem. 2009, 57, 5987-6000. [CrossRef]

61. Chorianopoulos, N.; Kalpoutzakis, E.; Aligiannis, N.; Mitaku, S.; Nychas, G.J.; Haroutounian, S.A. Essential oils of Satureja, Origanum, and Thymus species: Chemical composition and antibacterial activities against foodborne pathogens. J. Agric. Food Chem. 2004, 52, 8261-8267. [CrossRef]

62. Pirbalouti, A.G.; Chaleshtori, A.R.; Tajbakhsh, E.; Momtaz, H.; Rahimi, E.; Shahin, F. Bioactivity of medicinal plant extracts against Listeria monocytogenes isolated from food. J. Food Agric. Environ. 2009, 7, 66-69.

63. Araújo, C.; Sousa, M.J.; Ferreira, M.F.; Leao, C. Activity of essential oils from mediterranean Lamiaceae species against food spoilage yeasts. J. Food Prot. 2003, 66, 625-632. [CrossRef]

64. Lachowicz, K.J.; Jones, G.P.; Briggs, D.R.; Bienvenu, F.E.; Wan, J.; Wilcock, A.; Coventry, M.J. The synergistic preservative effects of the essential oils of sweet basil (Ocimum basilicum L.) against acid-tolerant food microflora. Lett. Appl. Microbiol. 1998, 26, 209-214. [CrossRef] [PubMed]

65. Delaquis, P.; Stanich, K.; Toivonen, P. Effect of $\mathrm{pH}$ on the inhibition of Listeria spp. by vanillin and vanillic acid. J. Food Prot. 2005, 68, 1472-1476. [CrossRef] [PubMed]

66. Delaquis, P. Antimicrobial activity of individual and mixed fractions of dill, cilantro, coriander and eucalyptus essential oils. Int. J. Food Microbiol. 2002, 74, 101-109. [CrossRef]

67. Gill, A.; Delaquis, P.; Russo, P.; Holley, R. Evaluation of antilisterial action of cilantro oil on vacuum packed ham. Int. J. Food Microbiol. 2002, 73, 83-92. [CrossRef]

68. Thongson, C.; Davidson, P.M.; Mahakarnchanakul, W.; Vibulsresth, P. Antimicrobial effect of Thai spices against Listeria monocytogenes and Salmonella Typhimurium DT104. J. Food Prot. 2005, 68, 2054-2058. [CrossRef]

69. Hammer, K.A.; Carson, C.F.; Riley, T.V. Antifungal activity of the components of Melaleuca alternifolia (tea tree) oil. J. Appl. Microbiol. 2003, 95, 853-860. [CrossRef]

70. Cox, S.D.; Mann, C.M.; Markham, J.L. Interactions between components of the essential oil of Melaleuca alternifolia. J. Appl. Microbiol. 2001, 91, 492-497. [CrossRef]

71. Delaquis, P.J.; Ward, S.M.; Holley, R.A.; Cliff, M.C.; Mazza, G. Microbiological, chemical and sensory properties of pre-cooked roast beef preserved with horseradish essential oil. J. Food Sci. 1999, 64, 519-524. [CrossRef]

72. Ward, S.M.; Delaquis, P.J.; Holley, R.A.; Mazza, G. Inhibition of spoilage and pathogenic bacteria on agar and pre-cooked roast beef by volatile horseradish distillates. Food Res. Int. 1998, 31, 19-26. [CrossRef]

73. Nadarajah, D.; Han, J.H.; Holley, R.A. Use of mustard flour to inactivate Escherichia coli O157:H7 in ground beef under nitrogen flushed packaging. Int. J. Food Microbiol. 2005, 99, 257-267. [CrossRef]

74. Delaquis, P.J.; Sholberg, P.L. Antimicrobial activity of gaseous allyl isothiocyanate. J. Food Prot. 1997, 60, 943-947. [CrossRef] [PubMed]

75. Wendorff, W.L.; Riha, W.E.; Muehlenkamp, E. Growth of molds on cheese treated with heat or liquid smoke. J. Food Prot. 1993, 56, 963-966. [CrossRef] [PubMed]

76. Payne, K.D.; Rico-Munoz, E.; Davidson, P.M. The antimicrobial activity of phenolic compounds against Listeria monocytogenes and their effectiveness in a model milk system. J. Food Prot. 1989, 52, 151-153. [CrossRef] [PubMed]

77. Herald, P.J.; Davidson, P.M. Antibacterial activity of selected hydroxycinnamic acids. J. Food Sci. 1983, 48, 1378-1379. [CrossRef]

78. Chipley, J.R.; Uraih, N. Inhibition of Aspergillus growth and aflatoxin release by derivatives of benzoic acid. Appl. Environ. Microbiol. 1980, 40, 352-357. [PubMed]

79. Ulate-Rodríguez, J.; Schafer, H.W.; Zottola, E.A.; Davidson, P.M. Inhibition of Listeria monocytogenes, Escherichia coli O157:H7, and Micrococcus luteus by linear furanocoumarins in culture media. J. Food Prot. 1997, 60, 1046-1049. [CrossRef] [PubMed]

80. Cushnie, T.P.T.; Lamb, A.J. Antimicrobial activity of flavonoids. Int. J. Antimicrob. Agents 2005, 26, 343-356. [CrossRef]

81. Kramer, B.; Thielmann, J.; Hickisch, A.; Muranyi, P.; Wunderlich, J.; Hauser, C. Antimicrobial activity of hop extracts against foodborne pathogens for meat applications. J. Appl. Microbiol. 2015, 118, 648-657. [CrossRef] 
82. Bogdanova, K.; Röderova, M.; Kolar, M.; Langova, K.; Dusek, M.; Jost, P.; Kubelkova, K.; Bostik, P.; Olsovska, J. Antibiofilm activity of bioactive hop compounds humulone, lupulone and xanthohumol toward susceptible and resistant staphylococci. Res. Microbiol. 2018, 169, 127-134. [CrossRef]

83. Fernandez, J.L.; Simpson, W.J. Aspects of the resistance of lactic acid bacteria to hop bitter acids. J. Appl. Bacteriol. 1993, 75, 315-319. [CrossRef]

84. Simpson, W.J.; Smith, A.R.W. Factors affecting antibacterial activity of hop compounds and their derivatives. J. Appl. Bacteriol. 1992, 72, 327-334. [CrossRef] [PubMed]

85. Haas, G.J.; Barsoumian, R. Antimicrobial activity of hop resins. J. Food Prot. 1994, 57, 59-61. [CrossRef] [PubMed]

86. Larson, A.E.; Yu, R.R.Y.; Lee, O.A.; Price, S.; Haas, G.J.; Johnson, E.A. Antimicrobial activity of hop extracts against Listeria monocytogenes in media and in food. Int. J. Food Microbiol. 1996, 33, 195-207. [CrossRef]

87. Bhattacharya, S.; Virani, S.; Zavro, M.; Haas, G.J. Inhibition of Streptococcus mutans and other oral Streptococci by hop (Humulus lupulus L.) constituents. Econ. Bot. 2003, 57, 118-125. [CrossRef]

88. Shen, C.; Geornaras, I.; Kendall, P.A.; Sofos, J.N. Control of Listeria monocytogenes on frankfurters by dipping in hops beta acids solutions. J. Food Prot. 2009, 72, 702-706. [CrossRef] [PubMed]

89. Mizobuchi, S.; Sato, Y. A new flavanone with antifungal activity isolated from hops. Agric. Biol. Chem. 1984, $48,2771-2775$.

90. Mizobuchi, S.; Sato, Y. Antifungal activities of hop bitter resins and related compounds. Agric. Biol. Chem. 1985, 49, 399-403.

91. Srinivasan, V.; Goldberg, D.; Haas, G.J. Contributions to the antimicrobial spectrum of hop constituents. Econ. Bot. 2004, 58, S230-S238. [CrossRef]

92. Ahn, J.; Grün, I.U.; Mustapha, A. Antimicrobial and antioxidant activities of natural extracts in vitro and in ground beef. J. Food Prot. 2004, 67, 148-155. [CrossRef]

93. Markin, D.; Duek, L.; Berdicevsky, I. In vitro antimicrobial activity of olive leaves. Antimikrobielle Wirksamkeit von Olivenblattern in vitro. Mycoses 2003, 46, 132-136. [CrossRef]

94. Dogasaki, C.; Shindo, T.; Furuhata, K.; Fukuyama, M. Identification of chemical structure of antibacterial components against Legionella pneumophila in a coffee beverage. Yakugaku Zasshi 2002, 122, 487-494. [CrossRef] [PubMed]

95. Ibrahim, S.; Salameh, M.; Phetsomphou, S.; Yang, H.; Seo, C. Application of caffeine, 1,3,7-trimethylxanthine, to control Escherichia coli O157:H7. Food Chem. 2006, 99, 645-650. [CrossRef]

96. Kim, S.; Fung, D.Y.C. Antibacterial effect of crude water-soluble arrowroot (Puerariae radix) tea extracts on food-borne pathogens in liquid medium. Lett. Appl. Microbiol. 2004, 39, 319-325. [CrossRef]

97. Shimamura, T.; Zhao, W.-H.; Hu, Z.-Q. Mechanism of action and potential for use of tea catechin as an antiinfective agent. Antiinfect. Agents Med. Chem. 2007, 6, 57-62. [CrossRef]

98. Lee, Y.-L.; Cesario, T.; Wang, Y.; Shanbrom, E.; Thrupp, L. Antibacterial activity of vegetables and juices. Nutrition 2003, 19, 994-996. [CrossRef]

99. Shan, B.; Cai, Y.-Z.; Brooks, J.D.; Corke, H. Antibacterial properties and major bioactive components of cinnamon stick (Cinnamomum burmannii): Activity against foodborne pathogenic bacteria. J. Agric. Food Chem. 2007, 55, 5484-5490. [CrossRef]

100. Sagdic, O.; Ozturk, I.; Yilmaz, M.T.; Yetim, H. Effect of grape pomace extracts obtained from different grape varieties on microbial quality of beef patty. J. Food Sci. 2011, 76, M515-M521. [CrossRef]

101. Friedman, M.; Henika, P.R.; Levin, C.E. Bactericidal activities of health-promoting, food-derived powders against the foodborne pathogens Escherichia coli, Listeria monocytogenes, Salmonella enterica, and Staphylococcus aureus. J. Food Sci. 2013, 78, M270-M275. [CrossRef]

102. Cicerale, S.; Conlan, X.A.; Barnett, N.W.; Keast, R.S.J. The concentration of oleocanthal in olive oil waste. Nat. Prod. Res. 2011, 25, 542-548. [CrossRef]

103. Kanatt, S.R.; Chander, R.; Sharma, A. Antioxidant and antimicrobial activity of pomegranate peel extract improves the shelf life of chicken products. Int. J. Food Sci. Technol. 2010, 45, 216-222. [CrossRef]

104. Agourram, A.; Ghirardello, D.; Rantsiou, K.; Zeppa, G.; Belviso, S.; Romane, A.; Oufdou, K.; Giordano, M. Phenolic content, antioxidant potential, and antimicrobial activities of fruit and vegetable by-product extracts. Int. J. Food Prop. 2013, 16, 1092-1104. [CrossRef]

105. Li, G.; Xu, Y.; Wang, X.; Zhang, B.; Shi, C.; Zhang, W.; Xia, X. Tannin-rich fraction from pomegranate rind damages membrane of Listeria monocytogenes. Foodborne Pathog. Dis. 2014, 11, 313-319. [CrossRef] [PubMed] 
106. Xu, Y.; Li, G.; Zhang, B.; Wu, Q.; Wang, X.; Xia, X. Tannin-rich pomegranate rind extracts reduce adhesion to and invasion of Caco-2 cells by Listeria monocytogenes and decrease its expression of virulence genes. J. Food Prot. 2015, 78, 128-133. [CrossRef] [PubMed]

107. Debnath, S.; Habibur Rahman, S.M.; Deshmukh, G.; Duganath, N.; Pranitha, C.; Chiranjeevi, A. Antimicrobial screening of various fruit seed extracts. Pharmacogn. J. 2011, 3, 83-86. [CrossRef]

108. Taveira, M.; Silva, L.R.; Vale-Silva, L.A.; Pinto, E.; Valentão, P.; Ferreres, F.; Guedes de Pinho, P.; Andrade, P.B. Lycopersicon esculentum seeds: An industrial byproduct as an antimicrobial agent. J. Agric. Food Chem. 2010, 58, 9529-9536. [CrossRef]

109. Esquivel, P.; Jiménez, V.M. Functional properties of coffee and coffee by-products. Food Res. Int. 2012, 46, 488-495. [CrossRef]

110. Murthy, P.S.; Naidu, M.M. Recovery of phenolic antioxidants and functional compounds from coffee industry by-products. Food Bioprocess Technol. 2012, 5, 897-903. [CrossRef]

111. Jenssen, H.; Hamill, P.; Hancock, R.E.W. Peptide antimicrobial agents. Clin. Microbiol. Rev. 2006, 19, $491-511$. [CrossRef]

112. Cole, A.M.; Weis, P.; Diamond, G. Isolation and characterization of pleurocidin, an antimicrobial peptide in the skin secretions of winter flounder. J. Biol. Chem. 1997, 272, 12008-12013. [CrossRef]

113. Burrowes, O.J.; Hadjicharalambous, C.; Diamond, G.; Lee, T.-C. Evaluation of antimicrobial spectrum and cytotoxic activity of pleurocidin for food applications. J. Food Sci. 2006, 69, FMS66-FMS71. [CrossRef]

114. Patrzykat, A.; Friedrich, C.L.; Zhang, L.; Mendoza, V.; Hancock, R.E.W. Sublethal concentrations of pleurocidin-derived antimicrobial peptides inhibit macromolecular synthesis in Escherichia coli. Antimicrob. Agents Chemother. 2002, 46, 605-614. [CrossRef] [PubMed]

115. Potter, R.; Truelstruphansen, L.; Gill, T. Inhibition of foodborne bacteria by native and modified protamine: Importance of electrostatic interactions. Int. J. Food Microbiol. 2005, 103, 23-34. [CrossRef] [PubMed]

116. Kim, Y.-H.; Kim, S.M.; Lee, S.Y. Antimicrobial activity of protamine against oral microorganisms. Biocontrol Sci. 2015, 20, 275-280. [CrossRef] [PubMed]

117. Zasloff, M. Magainins, a class of antimicrobial peptides from Xenopus skin: isolation, characterization of two active forms, and partial cDNA sequence of a precursor. Proc. Natl. Acad. Sci. USA 1987, 84, 5449-5453. [CrossRef] [PubMed]

118. Zasloff, M.; Martin, B.; Chen, H.C. Antimicrobial activity of synthetic magainin peptides and several analogues. Proc. Natl. Acad. Sci. USA 1988, 85, 910-913. [CrossRef]

119. Zucht, H.-D.; Raida, M.; Adermann, K.; Mägert, H.-J.; Forssmann, W.-G. Casocidin-I: a casein- $\alpha$ s2 derived peptide exhibits antibacterial activity. FEBS Lett. 1995, 372, 185-188. [CrossRef]

120. Murdock, C.A.; Cleveland, J.; Matthews, K.R.; Chikindas, M.L. The synergistic effect of nisin and lactoferrin on the inhibition of Listeria monocytogenes and Escherichia coli O157:H7. Lett. Appl. Microbiol. 2007, 44, 255-261. [CrossRef]

121. López-Expósito, I.; Pellegrini, A.; Amigo, L.; Recio, I. Synergistic effect between different milk-derived peptides and proteins. J. Dairy Sci. 2008, 91, 2184-2189. [CrossRef]

122. Juneja, V.K.; Dwivedi, H.P.; Yan, X. Novel natural food antimicrobials. Annu. Rev. Food Sci. Technol. 2012, 3, 381-403. [CrossRef]

123. Al-Nabulsi, A.A.; Holley, R.A. Effect of bovine lactoferrin against Carnobacterium viridans. Food Microbiol. 2005, 22, 179-187. [CrossRef]

124. Seifu, E.; Buys, E.M.; Donkin, E.F. Significance of the lactoperoxidase system in the dairy industry and its potential applications: a review. Trends Food Sci. Technol. 2005, 16, 137-154. [CrossRef]

125. Bafort, F.; Parisi, O.; Perraudin, J.-P.; Jijakli, M.H. Mode of action of lactoperoxidase as related to its antimicrobial activity: A review. Enzyme Res. 2014, 2014, 517164. [CrossRef] [PubMed]

126. Gay, M.; Amgar, A. Factors moderating Listeria monocytogenes growth in raw milk and in soft cheese made from raw milk. Lait 2005, 85, 153-170. [CrossRef]

127. Elliot, R.M.; McLay, J.C.; Kennedy, M.J.; Simmonds, R.S. Inhibition of foodborne bacteria by the lactoperoxidase system in a beef cube system. Int. J. Food Microbiol. 2004, 91, 73-81. [CrossRef]

128. McLay, J.; Kennedy, M.; O’Rourke, A.-L.; Elliot, R.; Simmonds, R. Inhibition of bacterial foodborne pathogens by the lactoperoxidase system in combination with monolaurin. Int. J. Food Microbiol. 2002, 73, 1-9. [CrossRef] 
129. Kennedy, M.; O’Rourke, A.-L.; McLay, J.; Simmonds, R. Use of a ground beef model to assess the effect of the lactoperoxidase system on the growth of Escherichia coli O157:H7, Listeria monocytogenes and Staphylococcus aureus in red meat. Int. J. Food Microbiol. 2000, 57, 147-158. [CrossRef]

130. Touch, V.; Hayakawa, S.; Yamada, S.; Kaneko, S. Effects of a lactoperoxidase-thiocyanate-hydrogen peroxide system on Salmonella enteritidis in animal or vegetable foods. Int. J. Food Microbiol. 2004, 93, 175-183. [CrossRef]

131. Jain, A.; Cheng, K. The principles and applications of avidin-based nanoparticles in drug delivery and diagnosis. J. Control. Release 2017, 245, 27-40. [CrossRef]

132. Nau, F.; Guérin-Dubiard, C.; Croguennec, T. Avidin. In Bioactive Egg Compounds; Springer: Berlin/Heidelberg, Germany, 2007; pp. 75-80. ISBN 9783540378839.

133. Diamandis, E.P.; Christopoulos, T.K. The biotin-(strept)avidin system: Principles and applications in biotechnology. Clin. Chem. 1991, 37, 625-636.

134. Maxwell, P.; Ibrahim, M. Immunocytochemistry. In Advanced Techniques in Diagnostic Cellular Pathology; John Wiley \& Sons, Ltd.: Chichester, UK, 2009; pp. 99-134. ISBN 9780470515976.

135. Kulagina, N.V.; Lassman, M.E.; Ligler, F.S.; Taitt, C.R. Antimicrobial peptides for detection of bacteria in biosensor assays. Anal. Chem. 2005, 77, 6504-6508. [CrossRef]

136. Juvonen, H.; Oja, T.; Määttänen, A.; Sarfraz, J.; Rosqvist, E.; Riihimäki, T.A.; Toivakka, M.; Kulomaa, M.; Vuorela, P.; Fallarero, A.; et al. Protein and bacterial interactions with nanostructured polymer coatings. Colloids Surf. B Biointerfaces 2015, 136, 527-535. [CrossRef] [PubMed]

137. Korpela, J.; Salonen, E.-M.; Kuusela, P.; Sarvas, M.; Vaheri, A. Binding of avidin to bacteria and to the outer membrane porin of Escherichia coli. FEMS Microbiol. Lett. 1984, 22, 3-10. [CrossRef]

138. Wu, J.; Acero-Lopez, A. Ovotransferrin: Structure, bioactivities, and preparation. Food Res. Int. 2012, 46, 480-487. [CrossRef]

139. Abeyrathne, E.D.N.S.; Lee, H.Y.; Ahn, D.U. Egg white proteins and their potential use in food processing or as nutraceutical and pharmaceutical agents-A review. Poult. Sci. 2013, 92, 3292-3299. [CrossRef]

140. Superti, F.; Ammendolia, M.G.; Berlutti, F.; Valenti, P. Ovotransferrin. In Bioactive Egg Compounds; Springer: Berlin/Heidelberg, Germany, 2007; pp. 43-50. ISBN 9783540378839.

141. Giansanti, F.; Leboffe, L.; Angelucci, F.; Antonini, G. The nutraceutical properties of ovotransferrin and its potential utilization as a functional food. Nutrients 2015, 7, 9105-9115. [CrossRef]

142. Hancock, R.E.W.; Scott, M.G. The role of antimicrobial peptides in animal defenses. Proc. Natl. Acad. Sci. USA 2000, 97, 8856-8861. [CrossRef]

143. Mine, Y.; Ma, F.; Lauriau, S. Antimicrobial peptides released by enzymatic hydrolysis of hen egg white lysozyme. J. Agric. Food Chem. 2004, 52, 1088-1094. [CrossRef]

144. Wang, G. Human antimicrobial peptides and proteins. Pharmaceuticals 2014, 7, 545-594. [CrossRef]

145. Ragland, S.A.; Criss, A.K. From bacterial killing to immune modulation: Recent insights into the functions of lysozyme. PLOS Pathog. 2017, 13, e1006512. [CrossRef]

146. Masschalck, B.; Michiels, C.W. Antimicrobial properties of lysozyme in relation to foodborne vegetative bacteria. Crit. Rev. Microbiol. 2003, 29, 191-214. [CrossRef]

147. Düring, K.; Porsch, P.; Mahn, A.; Brinkmann, O.; Gieffers, W. The non-enzymatic microbicidal activity of lysozymes. FEBS Lett. 1999, 449, 93-100. [CrossRef]

148. Ibrahim, H.R.; Matsuzaki, T.; Aoki, T. Genetic evidence that antibacterial activity of lysozyme is independent of its catalytic function. FEBS Lett. 2001, 506, 27-32. [CrossRef]

149. Eby, D.M.; Schaeublin, N.M.; Farrington, K.E.; Hussain, S.M.; Johnson, G.R. Lysozyme catalyzes the formation of antimicrobial silver nanoparticles. ACS Nano 2009, 3, 984-994. [CrossRef] [PubMed]

150. Park, S.-I.; Daeschel, M.A.; Zhao, Y. Functional properties of antimicrobial lysozyme-chitosan composite films. J. Food Sci. 2004, 69, M215-M221. [CrossRef]

151. Herbert, S.; Bera, A.; Nerz, C.; Kraus, D.; Peschel, A.; Goerke, C.; Meehl, M.; Cheung, A.; Götz, F. Molecular basis of resistance to muramidase and cationic antimicrobial peptide activity of lysozyme in Staphylococci. PLoS Pathog. 2007, 3, e102. [CrossRef]

152. Eby, D.M.; Luckarift, H.R.; Johnson, G.R. Hybrid antimicrobial enzyme and silver nanoparticle coatings for medical instruments. ACS Appl. Mater. Interfaces 2009, 1, 1553-1560. [CrossRef]

153. Bayarri, M.; Oulahal, N.; Degraeve, P.; Gharsallaoui, A. Properties of lysozyme/low methoxyl (LM) pectin complexes for antimicrobial edible food packaging. J. Food Eng. 2014, 131, 18-25. [CrossRef] 
154. Güçbilmez, Ç.M.; Yemenicioğlu, A.; Arslanoğlu, A. Antimicrobial and antioxidant activity of edible zein films incorporated with lysozyme, albumin proteins and disodium EDTA. Food Res. Int. 2007, 40, 80-91. [CrossRef]

155. Ibrahim, H.R.; Thomas, U.; Pellegrini, A. A helix-loop-helix peptide at the upper lip of the active site cleft of lysozyme confers potent antimicrobial activity with membrane permeabilization action. J. Biol. Chem. 2001, 276, 43767-43774. [CrossRef]

156. Oh, H.I.; Kim, Y.J.; Chang, E.J.; Kim, J.Y. Antimicrobial characteristics of chitosans against food spoilage microorganisms in liquid media and mayonnaise. Biosci. Biotechnol. Biochem. 2001, 65, 2378-2383. [CrossRef]

157. Rhoades, J.; Roller, S. Antimicrobial actions of degraded and native chitosan against spoilage organisms in laboratory media and foods. Appl. Environ. Microbiol. 2000, 66, 80-86. [CrossRef] [PubMed]

158. Roller, S.; Covill, N. The antimicrobial properties of chitosan in mayonnaise and mayonnaise-based shrimp salads. J. Food Prot. 2000, 63, 202-209. [CrossRef] [PubMed]

159. Sagoo, S.K.; Board, R.; Roller, S. Chitosan potentiates the antimicrobial action of sodium benzoate on spoilage yeasts. Lett. Appl. Microbiol. 2002, 34, 168-172. [CrossRef]

160. Tsai, G.-J.; Wu, Z.-Y.; Su, W.-H. Antibacterial activity of a chitooligosaccharide mixture prepared by cellulase digestion of shrimp chitosan and its application to milk preservation. J. Food Prot. 2000, 63, 747-752. [CrossRef]

161. Zivanovic, S.; Basurto, C.C.; Chi, S.; Davidson, P.M.; Weiss, J. Molecular weight of chitosan influences antimicrobial activity in oil-in-water emulsions. J. Food Prot. 2004, 67, 952-959. [CrossRef]

162. Moreira, M.d.R.; Pereda, M.; Marcovich, N.E.; Roura, S.I. Antimicrobial effectiveness of bioactive packaging materials from edible chitosan and casein polymers: Assessment on carrot, cheese, and salami. J. Food Sci. 2011, 76, M54-M63. [CrossRef]

163. Ben-Shalom, N.; Ardi, R.; Pinto, R.; Aki, C.; Fallik, E. Controlling gray mould caused by Botrytis cinerea in cucumber plants by means of chitosan. Crop Prot. 2003, 22, 285-290. [CrossRef]

164. Fernandes, J.C.; Tavaria, F.K.; Soares, J.C.; Ramos, Ó.S.; João Monteiro, M.; Pintado, M.E.; Xavier Malcata, F. Antimicrobial effects of chitosans and chitooligosaccharides, upon Staphylococcus aureus and Escherichia coli, in food model systems. Food Microbiol. 2008, 25, 922-928. [CrossRef]

165. Park, S.-I.; Stan, S.D.; Daeschel, M.A.; Zhao, Y. Antifungal coatings on fresh strawberries (Fragaria ananassa) to control mold growth during cold storage. J. Food Sci. 2006, 70, M202-M207. [CrossRef]

166. Pranoto, Y.; Rakshit, S.K.; Salokhe, V.M. Enhancing antimicrobial activity of chitosan films by incorporating garlic oil, potassium sorbate and nisin. LWT Food Sci. Technol. 2005, 38, 859-865. [CrossRef]

167. Devlieghere, F.; Vermeulen, A.; Debevere, J. Chitosan: antimicrobial activity, interactions with food components and applicability as a coating on fruit and vegetables. Food Microbiol. 2004, 21, 703-714. [CrossRef]

168. Sundaram, J.; Pant, J.; Goudie, M.J.; Mani, S.; Handa, H. Antimicrobial and physicochemical characterization of biodegradable, nitric oxide-releasing nanocellulose-chitosan packaging membranes. J. Agric. Food Chem. 2016, 64, 5260-5266. [CrossRef] [PubMed]

169. Torlak, E.; Sert, D. Antibacterial effectiveness of chitosan-propolis coated polypropylene films against foodborne pathogens. Int. J. Biol. Macromol. 2013, 60, 52-55. [CrossRef] [PubMed]

170. Torlak, E.; Nizamlioğlu, M. Antimicrobial effectiveness of chitosan-essential oil coated plastic films against foodborne pathogens. J. Plast. Film Sheeting 2011, 27, 235-248. [CrossRef]

171. Shaaban, H.A.; Ali, H.S.; Bareh, G.F.; Al-khalifa, A.R.S.; Amer, M.M. Antimicrobial activity of two polysaccharide edible films incorporated with essential oils against three pathogenic bacteria. J. Appl. Sci. 2017, 17, 171-183. [CrossRef]

172. Chung, Y.-C.; Yeh, J.-Y.; Tsai, C.-F. Antibacterial characteristics and activity of water-soluble chitosan derivatives prepared by the Maillard reaction. Molecules 2011, 16, 8504-8514. [CrossRef]

173. Young, D.H.; Köhle, H.; Kauss, H. Effect of chitosan on membrane permeability of suspension-cultured Glycine max and Phaseolus vulgaris cells. Plant Physiol. 1982, 70, 1449-1454. [CrossRef]

174. Knorr, D. Recovery and utilization of chitin and chitosan in food processing waste management. Food Technol. 1991, 45, 114-122.

175. Verlee, A.; Mincke, S.; Stevens, C.V. Recent developments in antibacterial and antifungal chitosan and its derivatives. Carbohydr. Polym. 2017, 164, 268-283. [CrossRef] 
176. Raafat, D.; von Bargen, K.; Haas, A.; Sahl, H.-G. Insights into the mode of action of chitosan as an antibacterial compound. Appl. Environ. Microbiol. 2008, 74, 3764-3773. [CrossRef]

177. Sudarshan, N.R.; Hoover, D.G.; Knorr, D. Antibacterial action of chitosan. Food Biotechnol. 1992, 6, $257-272$. [CrossRef]

178. Fei Liu, X.; Lin Guan, Y.; Zhi Yang, D.; Li, Z.; De Yao, K. Antibacterial action of chitosan and carboxymethylated chitosan. J. Appl. Polym. Sci. 2001, 79, 1324-1335. [CrossRef]

179. Andres, Y.; Giraud, L.; Gerente, C.; Le Cloirec, P. Antibacterial effects of chitosan powder: Mechanisms of action. Environ. Technol. 2007, 28, 1357-1363. [CrossRef] [PubMed]

180. Sprong, R.C.; Hulstein, M.F.E.; Van der Meer, R. Bactericidal activities of milk lipids. Antimicrob. Agents Chemother. 2001, 45, 1298-1301. [CrossRef]

181. Sprong, R.; Hulstein, M.F.; van der Meer, R. Bovine milk fat components inhibit food-borne pathogens. Int. Dairy J. 2002, 12, 209-215. [CrossRef]

182. Lock, A.L.; Bauman, D.E. Modifying milk fat composition of dairy cows to enhance fatty acids beneficial to human health. Lipids 2004, 39, 1197-1206. [CrossRef]

183. Hamosh, M. Protective function of proteins and lipids in human milk. Neonatology 1998, 74, $163-176$. [CrossRef]

184. German, J.B.; Dillard, C.J. Composition, structure and absorption of milk lipids: A source of energy, fat-soluble nutrients and bioactive molecules. Crit. Rev. Food Sci. Nutr. 2006, 46, 57-92. [CrossRef]

185. El Agamy, E.S.I.; Ruppanner, R.; Ismail, A.; Champagne, C.P.; Assaf, R. Antibacterial and antiviral activity of camel milk protective proteins. J. Dairy Res. 1992, 59, 169-175. [CrossRef]

186. Shin, S.Y.; Bajpai, V.K.; Kim, H.R.; Kang, S.C. Antibacterial activity of bioconverted eicosapentaenoic (EPA) and docosahexaenoic acid (DHA) against foodborne pathogenic bacteria. Int. J. Food Microbiol. 2007, 113, 233-236. [CrossRef]

187. Sun, M.; Dong, J.; Xia, Y.; Shu, R. Antibacterial activities of docosahexaenoic acid (DHA) and eicosapentaenoic acid (EPA) against planktonic and biofilm growing Streptococcus mutans. Microb. Pathog. 2017, 107, $212-218$. [CrossRef] [PubMed]

188. Desbois, A.P.; Smith, V.J. Antibacterial free fatty acids: activities, mechanisms of action and biotechnological potential. Appl. Microbiol. Biotechnol. 2010, 85, 1629-1642. [CrossRef] [PubMed]

189. Montville, T.J.; Chikindas, M.L. Biopreservation of foods. In Food Microbiology: Fundamentals and Frontiers, 3rd ed.; Doyle, M.P., Beuchat, L.R., Eds.; ASM Press: Washington, DC, USA, 2007; pp. 747-764. ISBN 978-1-55581-407-6.

190. Saleh, M.A.; Ordal, Z.J. Studies on growth and toxin production of Clostridium botulinum in a precooked frozen food. II. Inhibitioin by lactic acid bacteria. J. Food Sci. 1955, 20, 340-350. [CrossRef]

191. Ting, P.T.; Freiman, A. The story of Clostridium botulinum: From food poisoning to Botox. Clin. Med. 2004, 4, 258-261. [CrossRef]

192. Johnson, E.A. CLOSTRIDIUM|Clostridium botulinum. In Encyclopedia of Food Microbiology; Elsevier: Amsterdam, The Netherlands, 2014; pp. 458-462. ISBN 9780123847331.

193. Hutton, M.T.; Chehak, P.A.; Hanlin, J.H. Inhibition of botulinum toxin production by Pediococcus acidilactici in temperature abused refrigerated foods. J. Food Saf. 1991, 11, 255-267. [CrossRef]

194. Cintas, L.M.; Casaus, M.P.; Herranz, C.; Nes, I.F.; Hernández, P.E. Review: Bacteriocins of lactic acid bacteria. Food Sci. Technol. Int. 2001, 7, 281-305. [CrossRef]

195. Cotter, P.D.; Hill, C.; Ross, R.P. Bacteriocins: developing innate immunity for food. Nat. Rev. Microbiol. 2005, 3, 777-788. [CrossRef]

196. Reis, J.A.; Paula, A.T.; Casarotti, S.N.; Penna, A.L.B. Lactic acid bacteria antimicrobial compounds: Characteristics and applications. Food Eng. Rev. 2012, 4, 124-140. [CrossRef]

197. Klaenhammer, T. Genetics of bacteriocins produced by lactic acid bacteria. FEMS Microbiol. Rev. 1993, 12, 39-85. [CrossRef]

198. Cleveland, J.; Montville, T.J.; Nes, I.F.; Chikindas, M.L. Bacteriocins: safe, natural antimicrobials for food preservation. Int. J. Food Microbiol. 2001, 71, 1-20. [CrossRef]

199. Alvarez-Sieiro, P.; Montalbán-López, M.; Mu, D.; Kuipers, O.P. Bacteriocins of lactic acid bacteria: extending the family. Appl. Microbiol. Biotechnol. 2016, 100, 2939-2951. [CrossRef] [PubMed]

200. Perez, R.H.; Zendo, T.; Sonomoto, K. Novel bacteriocins from lactic acid bacteria (LAB): various structures and applications. Microb. Cell Fact. 2014, 13, S3. [CrossRef] [PubMed] 
201. Veskovic-Moracanin, S.; Djukic, D.; Memisi, N. Bacteriocins produced by lactic acid bacteria: A review. Acta Period. Technol. 2014, 2014, 271-283. [CrossRef]

202. De Vuyst, L.; Leroy, F. Bacteriocins from lactic acid bacteria: Production, purification, and food applications. J. Mol. Microbiol. Biotechnol. 2007, 13, 194-199. [CrossRef]

203. Woraprayote, W.; Malila, Y.; Sorapukdee, S.; Swetwiwathana, A.; Benjakul, S.; Visessanguan, W. Bacteriocins from lactic acid bacteria and their applications in meat and meat products. Meat Sci. 2016, 120, 118-132. [CrossRef]

204. Schillinger, U. Bacteriocins of lactic acid bacteria. In Biotechnology and Food Safety; Elsevier: Amsterdam, The Netherlands, 1990; pp. 55-74.

205. Kalchayanand, N.; Hanlin, M.B.; Ray, B. Sublethal injury makes Gram-negative and resistant Gram-positive bacteria sensitive to the bacteriocins, pediocin AcH and nisin. Lett. Appl. Microbiol. 1992, 15, $239-243$. [CrossRef]

206. Kalchayanand, N.; Sikes, T.; Dunne, C.P.; Ray, B. Hydrostatic pressure and electroporation have increased bactericidal efficiency in combination with bacteriocins. Appl. Environ. Microbiol. 1994, 60, 4174-4177.

207. Bali, V.; Panesar, P.S.; Bera, M.B. Potential of immobilization technology in bacteriocin production and antimicrobial packaging. Food Rev. Int. 2014, 30, 244-263. [CrossRef]

208. Mossallam, S.F.; Amer, E.I.; Diab, R.G. Potentiated anti-microsporidial activity of Lactobacillus acidophilus CH1 bacteriocin using gold nanoparticles. Exp. Parasitol. 2014, 144, 14-21. [CrossRef]

209. Gomaa, E.Z. Synergistic antibacterial efficiency of bacteriocin and silver nanoparticles produced by probiotic Lactobacillus paracasei against multidrug resistant bacteria. Int. J. Pept. Res. Ther. 2019, 25, 1113-1125. [CrossRef]

210. De Mello, M.B.; da Silva Malheiros, P.; Brandelli, A.; Pesce da Silveira, N.; Jantzen, M.M.; de Souza da Motta, A. Characterization and antilisterial effect of phosphatidylcholine nanovesicles containing the antimicrobial peptide pediocin. Probiotics Antimicrob. Proteins 2013, 5, 43-50. [CrossRef] [PubMed]

211. Bower, C.K.; McGuire, J.; Daeschel, M.A. Suppression of Listeria monocytogenes colonization following adsorption of nisin onto silica surfaces. Appl. Environ. Microbiol. 1995, 61, 992-997. [PubMed]

212. Daeschel, M.A.; McGuire, J.; Al-Makhlafi, H. Antimicrobial activity of nisin adsorbed to hydrophilic and hydrophobic silicon surfaces. J. Food Prot. 1992, 55, 731-735. [CrossRef]

213. Karam, L.; Jama, C.; Nuns, N.; Mamede, A.-S.; Dhulster, P.; Chihib, N.-E. Nisin adsorption on hydrophilic and hydrophobic surfaces: evidence of its interactions and antibacterial activity. J. Pept. Sci. 2013, 19, 377-385. [CrossRef]

214. Karam, L.; Jama, C.; Mamede, A.-S.; Boukla, S.; Dhulster, P.; Chihib, N.-E. Nisin-activated hydrophobic and hydrophilic surfaces: assessment of peptide adsorption and antibacterial activity against some food pathogens. Appl. Microbiol. Biotechnol. 2013, 97, 10321-10328. [CrossRef]

215. Karam, L.; Jama, C.; Mamede, A.-S.; Fahs, A.; Louarn, G.; Dhulster, P.; Chihib, N.-E. Study of nisin adsorption on plasma-treated polymer surfaces for setting up materials with antibacterial properties. React. Funct. Polym. 2013, 73, 1473-1479. [CrossRef]

216. Blay, G.L.; Lacroix, C.; Zihler, A.; Fliss, I. In vitro inhibition activity of nisin A, nisin Z, pediocin PA-1 and antibiotics against common intestinal bacteria. Lett. Appl. Microbiol. 2007, 45, 252-257. [CrossRef]

217. Todorov, S.D.; Wachsman, M.; Tomé, E.; Dousset, X.; Destro, M.T.; Dicks, L.M.T.; de Melo Franco, B.D.G.; Vaz-Velho, M.; Drider, D. Characterisation of an antiviral pediocin-like bacteriocin produced by Enterococcus faecium. Food Microbiol. 2010, 27, 869-879. [CrossRef]

218. Rodríguez, J.M.; Martínez, M.I.; Kok, J. Pediocin PA-1, a wide-spectrum bacteriocin from lactic acid bacteria. Crit. Rev. Food Sci. Nutr. 2002, 42, 91-121. [CrossRef]

219. Espitia, P.J.P.; Soares, N.d.F.F.; Teófilo, R.F.; Coimbra, J.S.d.R.; Vitor, D.M.; Batista, R.A.; Ferreira, S.O.; de Andrade, N.J.; Medeiros, E.A.A. Physical-mechanical and antimicrobial properties of nanocomposite films with pediocin and ZnO nanoparticles. Carbohydr. Polym. 2013, 94, 199-208. [CrossRef]

220. Gravesen, A.; Jydegaard Axelsen, A.-M.; Mendes da Silva, J.; Hansen, T.B.; Knochel, S. Frequency of bacteriocin resistance development and associated fitness costs in Listeria monocytogenes. Appl. Environ. Microbiol. 2002, 68, 756-764. [CrossRef] [PubMed]

221. Santiago-Silva, P.; Soares, N.F.F.; Nóbrega, J.E.; Júnior, M.A.W.; Barbosa, K.B.F.; Volp, A.C.P.; Zerdas, E.R.M.A.; Würlitzer, N.J. Antimicrobial efficiency of film incorporated with pediocin (ALTA ${ }^{\circledR} 2351$ ) on preservation of sliced ham. Food Control 2009, 20, 85-89. [CrossRef] 
222. Rodríguez, E.; Calzada, J.; Arqués, J.L.; Rodríguez, J.M.; Nuñez, M.; Medina, M. Antimicrobial activity of pediocin-producing Lactococcus lactis on Listeria monocytogenes, Staphylococcus aureus and Escherichia coli O157:H7 in cheese. Int. Dairy J. 2005, 15, 51-57. [CrossRef]

223. Millette, M.; Dupont, C.; Shareck, F.; Ruiz, M.T.; Archambault, D.; Lacroix, M. Purification and identification of the pediocin produced by Pediococcus acidilactici MM33, a new human intestinal strain. J. Appl. Microbiol. 2008, 104, 269-275. [CrossRef] [PubMed]

224. Nieto-Lozano, J.C.; Reguera-Useros, J.I.; Peláez-Martínez, M.d.C.; Sacristán-Pérez-Minayo, G.; Gutiérrez-Fernández, Á.J.; de la Torre, A.H. The effect of the pediocin PA-1 produced by Pediococcus acidilactici against Listeria monocytogenes and Clostridium perfringens in Spanish dry-fermented sausages and frankfurters. Food Control 2010, 21, 679-685. [CrossRef]

225. Renye, J.A.; Somkuti, G.A.; Garabal, J.I.; Du, L. Heterologous production of pediocin for the control of Listeria monocytogenes in dairy foods. Food Control 2011, 22, 1887-1892. [CrossRef]

226. Langa, S.; Landete, J.M.; Martín-Cabrejas, I.; Rodríguez, E.; Arqués, J.L.; Medina, M. In situ reuterin production by Lactobacillus reuteri in dairy products. Food Control 2013, 33, 200-206. [CrossRef]

227. Arqués, J.L.; Rodríguez, E.; Nuñez, M.; Medina, M. Combined effect of reuterin and lactic acid bacteria bacteriocins on the inactivation of food-borne pathogens in milk. Food Control 2011, 22, 457-461. [CrossRef]

228. Elsser-Gravesen, D.; Elsser-Gravesen, A. Biopreservatives. In Advances in Biochemical Engineering/Biotechnology; Springer: Berlin/Heidelberg, Germany, 2013; pp. 29-49.

229. Fontana, C.; Fadda, S.; Cocconcelli, P.S.; Vignolo, G. Lactic acid bacteria in meat fermentations. In Lactic Acid Bacteria: Microbiological and Functional Aspects, Fourth Edition; CRC Press: Boca Raton, FL, USA, 2011; pp. 247-264. ISBN 9781439836781.

230. Lu, S.; Xu, X.; Zhou, G.; Zhu, Z.; Meng, Y.; Sun, Y. Effect of starter cultures on microbial ecosystem and biogenic amines in fermented sausage. Food Control 2010, 21, 444-449. [CrossRef]

231. Freire, A.L.; Ramos, C.L.; da Costa Souza, P.N.; Cardoso, M.G.B.; Schwan, R.F. Nondairy beverage produced by controlled fermentation with potential probiotic starter cultures of lactic acid bacteria and yeast. Int. J. Food Microbiol. 2017, 248, 39-46. [CrossRef]

232. De Melo Pereira, G.V.; Neto, E.; Soccol, V.T.; Medeiros, A.B.P.; Woiciechowski, A.L.; Soccol, C.R. Conducting starter culture-controlled fermentations of coffee beans during on-farm wet processing: Growth, metabolic analyses and sensorial effects. Food Res. Int. 2015, 75, 348-356. [CrossRef] [PubMed]

233. Garofalo, C.; El Khoury, M.; Lucas, P.; Bely, M.; Russo, P.; Spano, G.; Capozzi, V. Autochthonous starter cultures and indigenous grape variety for regional wine production. J. Appl. Microbiol. 2015, 118, 1395-1408. [CrossRef] [PubMed]

234. Ming, X.; Daeschel, M.A. Nisin resistance of foodborne bacteria and the specific resistance responses of Listeria monocytogenes Scott A. J. Food Prot. 1993, 56, 944-948. [CrossRef] [PubMed]

235. Turovskiy, Y.; Rosenberg, L.; Chikindas, M.L. Autoinducer-2-mediated quorum sensing is not involved in Listeria monocytogenes' adaptive responses to the food preservatives lactic acid and nisin. J. Food Saf. 2007, 27, 386-399. [CrossRef]

236. Mazzotta, A.S.; Crandall, A.D.; Montville, T.J. Nisin resistance in Clostridium botulinum spores and vegetative cells. Appl. Environ. Microbiol. 1997, 63, 2654-2659.

237. Naghmouchi, K.; Kheadr, E.; Lacroix, C.; Fliss, I. Class I/Class IIa bacteriocin cross-resistance phenomenon in Listeria monocytogenes. Food Microbiol. 2007, 24, 718-727. [CrossRef]

238. Laursen, M.F.; Bahl, M.I.; Licht, T.R.; Gram, L.; Knudsen, G.M. A single exposure to a sublethal pediocin concentration initiates a resistance-associated temporal cell envelope and general stress response in Listeria monocytogenes. Environ. Microbiol. 2015, 17, 1134-1151. [CrossRef]

239. Hanlin, M.B.; Kalchayanand, N.; Ray, P.; Ray, B. Bacteriocins of lactic acid bacteria in combination have greater antibacterial activity. J. Food Prot. 1993, 56, 252-255. [CrossRef]

240. Field, D.; Ross, R.P.; Hill, C. Developing bacteriocins of lactic acid bacteria into next generation biopreservatives. Curr. Opin. Food Sci. 2018, 20, 1-6. [CrossRef]

241. Rekhif, N.; Atrih, A.; Lefebvre, G. Selection and properties of spontaneous mutants of Listeria monocytogenes ATCC 15313 resistant to different bacteriocins produced by lactic acid bacteria strains. Curr. Microbiol. 1994, 28, 237-241. [CrossRef] 
242. Kaur, G.; Singh, T.P.; Malik, R.K. Antibacterial efficacy of nisin, pediocin 34 and enterocin FH99 against Listeria monocytogenes and cross resistance of its bacteriocin resistant variants to common food preservatives. Brazilian J. Microbiol. 2013, 44, 63-71. [CrossRef] [PubMed]

243. Kaur, G.; Singh, T.P.; Malik, R.K.; Bhardwaj, A.; De, S. Antibacterial efficacy of nisin, pediocin 34 and enterocin FH99 against L. monocytogenes, E. faecium and E. faecalis and bacteriocin cross resistance and antibiotic susceptibility of their bacteriocin resistant variants. J. Food Sci. Technol. 2014, 51, 233-244. [CrossRef] [PubMed]

244. Gravesen, A.; Kallipolitis, B.; Holmstrom, K.; Hoiby, P.E.; Ramnath, M.; Knochel, S. pbp2229-mediated nisin resistance mechanism in Listeria monocytogenes confers cross-protection to Class IIa bacteriocins and affects virulence gene expression. Appl. Environ. Microbiol. 2004, 70, 1669-1679. [CrossRef] [PubMed]

245. Jończyk, E.; Kłak, M.; Międzybrodzki, R.; Górski, A. The influence of external factors on bacteriophages-review. Folia Microbiol. 2011, 56, 191-200. [CrossRef]

246. Nobrega, F.L.; Vlot, M.; de Jonge, P.A.; Dreesens, L.L.; Beaumont, H.J.E.; Lavigne, R.; Dutilh, B.E.; Brouns, S.J.J. Targeting mechanisms of tailed bacteriophages. Nat. Rev. Microbiol. 2018, 16, 760-773. [CrossRef]

247. García, P.; Rodríguez, L.; Rodríguez, A.; Martínez, B. Food biopreservation: promising strategies using bacteriocins, bacteriophages and endolysins. Trends Food Sci. Technol. 2010, 21, 373-382. [CrossRef]

248. León, M.; Bastías, R. Virulence reduction in bacteriophage resistant bacteria. Front. Microbiol. 2015, 6, 343. [CrossRef]

249. Brüssow, H. Phage therapy: The Escherichia coli experience. Microbiology 2005, 151, 2133-2140. [CrossRef]

250. Haq, I.U.; Chaudhry, W.N.; Akhtar, M.N.; Andleeb, S.; Qadri, I. Bacteriophages and their implications on future biotechnology: a review. Virol. J. 2012, 9, 9. [CrossRef]

251. Golkar, Z.; Bagasra, O.; Pace, D.G. Bacteriophage therapy: a potential solution for the antibiotic resistance crisis. J. Infect. Dev. Ctries. 2014, 8, 129-136. [CrossRef]

252. García, P.; Martínez, B.; Obeso, J.M.; Rodríguez, A. Bacteriophages and their application in food safety. Lett. Appl. Microbiol. 2008, 47, 479-485. [CrossRef] [PubMed]

253. Mahony, J.; McAuliffe, O.; Ross, R.P.; van Sinderen, D. Bacteriophages as biocontrol agents of food pathogens. Curr. Opin. Biotechnol. 2011, 22, 157-163. [CrossRef] [PubMed]

254. Marcó, M.B.; Moineau, S.; Quiberoni, A. Bacteriophages and dairy fermentations. Bacteriophage 2012, 2, 149-158. [CrossRef] [PubMed]

255. Schmelcher, M.; Loessner, M.J. Application of bacteriophages for detection of foodborne pathogens. Bacteriophage 2014, 4, e28137. [CrossRef]

256. Joerger, R. Alternatives to antibiotics: bacteriocins, antimicrobial peptides and bacteriophages. Poult. Sci. 2003, 82, 640-647. [CrossRef]

257. Wijesekara, I.; Pangestuti, R.; Kim, S.-K. Biological activities and potential health benefits of sulfated polysaccharides derived from marine algae. Carbohydr. Polym. 2011, 84, 14-21. [CrossRef]

258. Singh, S.; Kate, B.N.; Banerjee, U.C. Bioactive compounds from Cyanobacteria and Microalgae: An overview. Crit. Rev. Biotechnol. 2005, 25, 73-95. [CrossRef]

259. Borowitzka, M.A. Microalgae as sources of pharmaceuticals and other biologically active compounds. J. Appl. Phycol. 1995, 7, 3-15. [CrossRef]

260. Herrero, M.; Mendiola, J.A.; Plaza, M.; Ibañez, E. Screening for bioactive compounds from Algae. In Advanced Biofuels and Bioproducts; Springer: New York, NY, USA, 2013; pp. 833-872. ISBN 9781461433484.

261. Devi, K.P.; Suganthy, N.; Kesika, P.; Pandian, S.K. Bioprotective properties of seaweeds: In vitro evaluation of antioxidant activity and antimicrobial activity against food borne bacteria in relation to polyphenolic content. BMC Complement. Altern. Med. 2008, 8, 38. [CrossRef]

262. Gupta, S.; Rajauria, G.; Abu-Ghannam, N. Study of the microbial diversity and antimicrobial properties of Irish edible brown seaweeds. Int. J. Food Sci. Technol. 2010, 45, 482-489. [CrossRef]

263. Dussault, D.; Vu, K.D.; Vansach, T.; Horgen, F.D.; Lacroix, M. Antimicrobial effects of marine algal extracts and cyanobacterial pure compounds against five foodborne pathogens. Food Chem. 2016, 199, 114-118. [CrossRef] [PubMed]

264. Tavassoli-Kafrani, E.; Shekarchizadeh, H.; Masoudpour-Behabadi, M. Development of edible films and coatings from alginates and carrageenans. Carbohydr. Polym. 2016, 137, 360-374. [CrossRef] [PubMed] 
265. Alboofetileh, M.; Rezaei, M.; Hosseini, H.; Abdollahi, M. Antimicrobial activity of alginate/clay nanocomposite films enriched with essential oils against three common foodborne pathogens. Food Control 2014, 36, 1-7. [CrossRef]

266. Olaimat, A.N.; Fang, Y.; Holley, R.A. Inhibition of Campylobacter jejuni on fresh chicken breasts by $\mathrm{K}$-carrageenan/chitosan-based coatings containing allyl isothiocyanate or deodorized oriental mustard extract. Int. J. Food Microbiol. 2014, 187, 77-82. [CrossRef]

267. Olaimat, A.N.; Holley, R.A. Control of Salmonella on fresh chicken breasts by K-carrageenan/chitosan-based coatings containing allyl isothiocyanate or deodorized Oriental mustard extract plus EDTA. Food Microbiol. 2015, 48, 83-88. [CrossRef]

268. Ramesh, C.; Pattar, M.G. Antimicrobial properties, antioxidant activity and bioactive compounds from six wild edible mushrooms of western ghats of Karnataka, India. Pharmacognosy Res. 2010, 2, 107-112.

269. Öztürk, M.; Duru, M.E.; Kivrak, Ş.; Mercan-Doğan, N.; Türkoglu, A.; Özler, M.A. In vitro antioxidant, anticholinesterase and antimicrobial activity studies on three Agaricus species with fatty acid compositions and iron contents: A comparative study on the three most edible mushrooms. Food Chem. Toxicol. 2011, 49, 1353-1360. [CrossRef]

270. Kalyoncu, F.; Oskay, M.; Sağlam, H.; Erdoğan, T.F.; Tamer, A.Ü. Antimicrobial and antioxidant activities of mycelia of 10 wild mushroom species. J. Med. Food 2010, 13, 415-419. [CrossRef]

271. Shen, H.-S.; Shao, S.; Chen, J.-C.; Zhou, T. Antimicrobials from mushrooms for assuring food safety. Compr. Rev. Food Sci. Food Saf. 2017, 16, 316-329. [CrossRef]

272. Alves, M.; Ferreira, I.; Dias, J.; Teixeira, V.; Martins, A.; Pintado, M. A review on antimicrobial activity of mushroom (Basidiomycetes) extracts and isolated compounds. Planta Med. 2012, 78, 1707-1718. [CrossRef]

273. Lallawmsanga; Passari, A.K.; Mishra, V.K.; Leo, V.V.; Singh, B.P.; Valliammai Meyyappan, G.; Gupta, V.K.; Uthandi, S.; Upadhyay, R.C. Antimicrobial potential, identification and phylogenetic affiliation of wild mushrooms from two sub-tropical semi-evergreen indian forest ecosystems. PLoS ONE 2016, 11, e0166368. [CrossRef] [PubMed]

274. Alves, M.; Ferreira, I.; Lourenço, I.; Costa, E.; Martins, A.; Pintado, M. Wild mushroom extracts as inhibitors of bacterial biofilm formation. Pathogens 2014, 3, 667-679. [CrossRef] [PubMed]

275. Soković, M.; Glamočlija, J.; Marin, P.D.; Brkić, D.; van Griensven, L.J. Antibacterial effects of the essential oils of commonly consumed medicinal herbs using an in vitro model. Molecules 2010, 15, 7532-7546.

276. Ultee, A.; Slump, R.A.; Steging, G.; Smid, E.J. Antimicrobial activity of carvacrol toward Bacillus cereus on rice. J. Food Prot. 2000, 63, 620-624. [CrossRef]

277. Ayari, S.; Dussault, D.; Hamdi, M.; Lacroix, M. Growth and toxigenic potential of Bacillus cereus during storage temperature abuse in cooked irradiated chicken rice in combination with nisin and carvacrol. LWT Food Sci. Technol. 2016, 72, 19-25. [CrossRef]

278. Yuste, J.; Fung, D.Y.C. Inactivation of Listeria monocytogenes Scott A 49594 in apple juice supplemented with cinnamon. J. Food Prot. 2002, 65, 1663-1666. [CrossRef]

279. Cava, R.; Nowak, E.; Taboada, A.; Marin-Iniesta, F. Antimicrobial activity of clove and cinnamon essential oils against Listeria monocytogenes in pasteurized milk. J. Food Prot. 2007, 70, 2757-2763. [CrossRef]

280. Smith-Palmer, A.; Stewart, J.; Fyfe, L. The potential application of plant essential oils as natural food preservatives in soft cheese. Food Microbiol. 2001, 18, 463-470. [CrossRef]

281. Khorshidian, N.; Yousefi, M.; Khanniri, E.; Mortazavian, A.M. Potential application of essential oils as antimicrobial preservatives in cheese. Innov. Food Sci. Emerg. Technol. 2018, 45, 62-72. [CrossRef]

282. Hyun, J.-E.; Bae, Y.-M.; Yoon, J.-H.; Lee, S.-Y. Preservative effectiveness of essential oils in vapor phase combined with modified atmosphere packaging against spoilage bacteria on fresh cabbage. Food Control 2015, 51, 307-313. [CrossRef]

283. Karabagias, I.; Badeka, A.; Kontominas, M.G. Shelf life extension of lamb meat using thyme or oregano essential oils and modified atmosphere packaging. Meat Sci. 2011, 88, 109-116. [CrossRef] [PubMed]

284. Solomakos, N.; Govaris, A.; Koidis, P.; Botsoglou, N. The antimicrobial effect of thyme essential oil, nisin, and their combination against Listeria monocytogenes in minced beef during refrigerated storage. Food Microbiol. 2008, 25, 120-127. [CrossRef] [PubMed]

285. Solomakos, N.; Govaris, A.; Koidis, P.; Botsoglou, N. The antimicrobial effect of thyme essential oil, nisin and their combination against Escherichia coli O157:H7 in minced beef during refrigerated storage. Meat Sci. 2008, 80, 159-166. [CrossRef] [PubMed] 
286. Piskernik, S.; Klančnik, A.; Riedel, C.T.; Brøndsted, L.; Možina, S.S. Reduction of Campylobacter jejuni by natural antimicrobials in chicken meat-related conditions. Food Control 2011, 22, 718-724. [CrossRef]

287. DjEnane, D.; Yangüela, J.; Gómez, D.; Roncalés, P. Perspectives on the use of essential oils as antimicrobials against Campylobacter jejuni CECT 7572 in retail chicken meats packaged in microaerobic atmosphere. J. Food Saf. 2012, 32, 37-47. [CrossRef]

288. Jang, S.-A.; Shin, Y.-J.; Song, K. Bin Effect of rapeseed protein-gelatin film containing grapefruit seed extract on 'Maehyang' strawberry quality. Int. J. Food Sci. Technol. 2011, 46, 620-625. [CrossRef]

289. Muriel-Galet, V.; Cerisuelo, J.P.; López-Carballo, G.; Lara, M.; Gavara, R.; Hernández-Muñoz, P. Development of antimicrobial films for microbiological control of packaged salad. Int. J. Food Microbiol. 2012, 157, 195-201. [CrossRef]

290. Muriel-Galet, V.; Cerisuelo, J.P.; López-Carballo, G.; Aucejo, S.; Gavara, R.; Hernández-Muñoz, P. Evaluation of EVOH-coated PP films with oregano essential oil and citral to improve the shelf-life of packaged salad. Food Control 2013, 30, 137-143. [CrossRef]

291. Cé, N.; Noreña, C.P.Z.; Brandelli, A. Antimicrobial activity of chitosan films containing nisin, peptide P34, and natamycin. CyTA J. Food 2012, 10, 21-26. [CrossRef]

292. Jiang, Y.; Li, Y. Effects of chitosan coating on postharvest life and quality of longan fruit. Food Chem. 2001, 73, 139-143. [CrossRef]

293. Arnon, H.; Zaitsev, Y.; Porat, R.; Poverenov, E. Effects of carboxymethyl cellulose and chitosan bilayer edible coating on postharvest quality of citrus fruit. Postharvest Biol. Technol. 2014, 87, 21-26. [CrossRef]

294. Hong, K.; Xie, J.; Zhang, L.; Sun, D.; Gong, D. Effects of chitosan coating on postharvest life and quality of guava (Psidium guajava L.) fruit during cold storage. Sci. Hortic. 2012, 144, 172-178. [CrossRef]

295. Jianglian, D. Application of chitosan based coating in fruit and vegetable preservation: A review. J. Food Process. Technol. 2013, 4, 227. [CrossRef]

296. Romanazzi, G.; Feliziani, E.; Baños, S.B.; Sivakumar, D. Shelf life extension of fresh fruit and vegetables by chitosan treatment. Crit. Rev. Food Sci. Nutr. 2017, 57, 579-601. [CrossRef] [PubMed]

297. Vodnar, D.C. Inhibition of Listeria monocytogenes ATCC 19115 on ham steak by tea bioactive compounds incorporated into chitosan-coated plastic films. Chem. Cent. J. 2012, 6, 74. [CrossRef]

298. Park, S.; Marsh, K.S.; Dawson, P. Application of chitosan-incorporated LDPE film to sliced fresh red meats for shelf life extension. Meat Sci. 2010, 85, 493-499. [CrossRef]

299. Cardoso, G.P.; Dutra, M.P.; Fontes, P.R.; de Lemos Souza Ramos, A.; de Miranda Gomide, L.A.; Ramos, E.M. Selection of a chitosan gelatin-based edible coating for color preservation of beef in retail display. Meat Sci. 2016, 114, 85-94. [CrossRef]

300. Quesada, J.; Sendra, E.; Navarro, C.; Sayas-Barberá, E. Antimicrobial active packaging including chitosan films with Thymus vulgaris L. essential oil for ready-to-eat meat. Foods 2016, 5, 57. [CrossRef]

301. Sivarooban, T.; Hettiarachchy, N.S.; Johnson, M.G. Physical and antimicrobial properties of grape seed extract, nisin, and EDTA incorporated soy protein edible films. Food Res. Int. 2008, 41, 781-785. [CrossRef]

302. Zou, Y.; Lee, H.-Y.; Seo, Y.-C.; Ahn, J. Enhanced antimicrobial activity of nisin-loaded liposomal nanoparticles against foodborne pathogens. J. Food Sci. 2012, 77, M165-M170. [CrossRef]

303. Field, D.; Begley, M.; O'Connor, P.M.; Daly, K.M.; Hugenholtz, F.; Cotter, P.D.; Hill, C.; Ross, R.P. Bioengineered nisin A derivatives with enhanced activity against both Gram positive and Gram negative pathogens. PLoS ONE 2012, 7, e46884. [CrossRef] [PubMed]

304. Chatzidaki, M.D.; Balkiza, F.; Gad, E.; Alexandraki, V.; Avramiotis, S.; Georgalaki, M.; Papadimitriou, V.; Tsakalidou, E.; Papadimitriou, K.; Xenakis, A. Reverse micelles as nano-carriers of nisin against foodborne pathogens. Part II: The case of essential oils. Food Chem. 2019, 278, 415-423. [CrossRef] [PubMed]

(C) 2019 by the authors. Licensee MDPI, Basel, Switzerland. This article is an open access article distributed under the terms and conditions of the Creative Commons Attribution (CC BY) license (http://creativecommons.org/licenses/by/4.0/). 